\title{
Effect of Ripening on the Phenolic Composition and Mineral Content of Three Varieties of Olive Fruits
}

\author{
María del Pilar Fernández-Poyatos, Eulogio J. Llorent-Martínez (D) and Antonio Ruiz-Medina *(D)
}

check for updates

Citation: Fernández-Poyatos, M.d.P. Llorent-Martínez, E.J.; Ruiz-Medina, A. Effect of Ripening on the Phenolic Composition and Mineral Content of Three Varieties of Olive Fruits. Foods 2021, 10, 380. https://doi.org/ $10.3390 /$ foods 10020380

Academic Editor:

Beatriz Gandul-Rojas

Received: 8 January 2021

Accepted: 7 February 2021

Published: 9 February 2021

Publisher's Note: MDPI stays neutral with regard to jurisdictional claims in published maps and institutional affiliations.

Copyright: (c) 2021 by the authors. Licensee MDPI, Basel, Switzerland. This article is an open access article distributed under the terms and conditions of the Creative Commons Attribution (CC BY) license (https:// creativecommons.org/licenses/by/ $4.0 /)$.
Department of Physical and Analytical Chemistry, Faculty of Experimental Sciences, University of Jaén, Campus Las Lagunillas, E-23071 Jaén, Spain; mpoyatos@ujaen.es (M.d.P.F.-P.); ellorent@ujaen.es (E.J.L.-M.)

* Correspondence: anruiz@ujaen.es; Tel.: +34-953-212759

\begin{abstract}
The phenolic composition and mineral content of Cornezuelo, Cornicabra and Picual olive fruit varieties were investigated during olive ripening in two different harvesting seasons (2017/2018 and 2018/2019). Phytochemical profiles were evaluated by high-performance liquid chromatography (HPLC) with diode-array and mass spectrometry detection. Mineral contents were determined by inductively coupled plasma-mass spectrometry (ICP-MS). Twenty-five compounds were characterized and the main ones quantified. These compounds corresponded mostly to secoiridoids, the main ones being oleuropein, oleoside/secologanoside, oleoside-11-methylester, and oleuropein and comselogoside isomers. Total phenolic contents reached the highest values between December and January, coinciding with the usual harvesting date. This trend was observed in both harvesting seasons, although higher phenolic contents were recorded in season 2018/2019. This was due to the different weather conditions, which caused a lower olive production in season $2017 / 2018$. No clear tendency was observed between mineral content and harvest time in any of the studied seasons. The highest concentration of total phenolics was obtained in Cornezuelo variety (840 mg/100 g) in January 2019 (season 2018/2019). Picual and Cornicabra varieties reached concentrations of $670 \mathrm{mg} / 100 \mathrm{~g}$ and $530 \mathrm{mg} / 100 \mathrm{~g}$, respectively, also in the last harvesting dates of season 2018/2019.
\end{abstract}

Keywords: olives; Olea europaea; Cornezuelo; Cornicabra; Picual; phenolic; oleuropein

\section{Introduction}

Olea europaea L., belonging to the Oleaceae family, is one of the most important fruit trees in the Mediterranean area. It is widely cultivated in countries of southern Europe that border the Mediterranean Sea and in North Africa [1]. Spain has more than 2 million and a half hectares of olive groves, being the main producer of fresh olives, ahead of Italy and Greece, and the first producer in the world for table olives [2]. The quality of the olive fruits is affected by maturity at the time of harvest [3]. The phenolic compositionwhich is important in several aspects—varies qualitatively and quantitatively during fruit ripening [4]. These biochemical changes affect the texture, flavour and colour, which determine the organoleptic and nutritional quality of the fruits [5]. The main classes of phenols in olive fruits are phenolic acids, phenolic alcohols, flavonoids, and secoiridoids, with the last one being exclusively present in the Oleaceae family [6]. Oleuropein is the principal secoiridoid present in olive fruits. The great interest in olive polyphenols is due to their importance for human health, being a very healthy complement in the Mediterranean diet. In fact, numerous studies have shown evidence for their therapeutic and nutritional properties [7]. For instance, the decline of people with cardiovascular diseases in the Mediterranean Basin has been attributed in part to the consumption of olive products [8]. Polyphenols act as antioxidants and radical scavengers and are considered safe sources of natural antioxidants in the food industry [9].

Two of the most typical olive varieties in Spain are Cornicabra and Picual, known for the excellent quality of their (extra) virgin olive oils. Several studies have been carried out in these two varieties to study the effect of olive ripening on the content of polyphenols in 
olive fruits [10-13] and olive oils [10,14,15]. On the other hand, the Cornezuelo variety is less known, and the few studies regarding this variety have focused on olive oil, including organoleptic characteristics, fatty acids, triglycerides, and sterols [16,17]. However, Cornezuelo olives are increasing their popularity due to their excellent organoleptic characteristics, so the composition of their fruits was recently reported [18]. To our knowledge, this is the first report on the effects of the ripening process on Cornezuelo olive fruits.

The main purpose of this work was to identify and quantify phenolic compounds during the maturation process of the fruits of three Spanish cultivars (Cornezuelo, Cornicabra and Picual) in two different harvesting seasons and compare the results among the varieties. The secondary objective was to compare the concentration of phenolics in Cornezuelo (the least studied variety among the three here discussed) with Cornicabra and Picual. Additionally, the inorganic content of each of the varieties during their maturation was measured by inductively coupled plasma-mass spectrometry (ICP-MS), not only to provide data concerning their mineral content but also to ensure the absence of heavy metals considering that these olive fruits are intended for the production of olive oil. The main hypothesis is that phenolic content will vary between the different olive varieties and during the maturation process (following a similar trend concerning variations in concentration). The second hypothesis is that phenolic levels will be higher on the usual collection dates, when the maturation of the olives is considered optimal. The last hypothesis is that the phenolic content of Cornezuelo olive fruits will be similar or higher than the contents of the other two varieties.

\section{Material and Methods}

\subsection{Chemicals and Reagents}

All analytical standards were purchased from Sigma-Aldrich (Madrid, Spain). Solutions were prepared in HPLC-grade methanol (Sigma-Aldrich). LC-MS grade formic acid $(\mathrm{HCOOH})$, acetonitrile $\left(\mathrm{CH}_{3} \mathrm{CN}\right)$ and ultrapure water were also used.

Hydrogen peroxide $\left(\mathrm{H}_{2} \mathrm{O}_{2}\right.$; ultra-trace analysis) and nitric acid $\left(\mathrm{HNO}_{3} ; 65 \%\right.$; purified by sub-boiling distillation) were purchased from Panreac (Madrid, Spain). HPLC-grade n-hexane (>95\%) was obtained from Alfa Aesar (Haverhill, MA, USA).

For ICP-MS analysis, NIST-3281 (cranberry fruit) certified reference material was used.

\subsection{Sample Preparation and Extraction}

Olives cv. Cornicabra and cv. Picual were collected by hand in an olive grove in Albanchez de Mágina (Jaén, southeast of Spain; $37^{\circ} 47^{\prime} 40.6^{\prime \prime} \mathrm{N} 3^{\circ} 28^{\prime} 17.3^{\prime \prime} \mathrm{W}, 891 \mathrm{~m}$ a.s.l.) and Cornezuelo olive fruits were picked up in Torres (Jaén, southeast of Spain; $37^{\circ} 46^{\prime} 58.8^{\prime \prime} \mathrm{N}$ $3^{\circ} 30^{\prime} 59.9^{\prime \prime} \mathrm{W}, 894 \mathrm{~m}$ a.s.1.).

The study was performed during two consecutive harvesting seasons. The first season corresponded to the olive fruits collected in 2017/2018 on three different harvest dates (HD): 1 November 2017 (2nd HD); 6 December 2017 (3rd HD); 10 January 2018 (4th HD). During this season, samples were not collected before November because olive fruits were still scarce and very small. The second season corresponded to the samples collected in 2018/2019 on four dates: 19 October 2018 (1st HD); 16 November 2018 (2nd HD); 13 December 2018 (3rd HD); 16 January 2019 (4th HD). The last HD for both seasons corresponded to the final HD performed by olive farmers. Compounds identification for each HD is shown in Table 1.

Maturity indexes (MI) for each variety during the different HDs are shown in Tables 2-4. MI was determined on 100 randomly selected olives [19]. 
Table 1. HPLC-ESI-MS ${ }^{\mathrm{n}}$ characterization of phytochemicals in extracts of Cornezuelo, Cornicabra and Picual olive fruits in different months of season $2018 / 2019$.

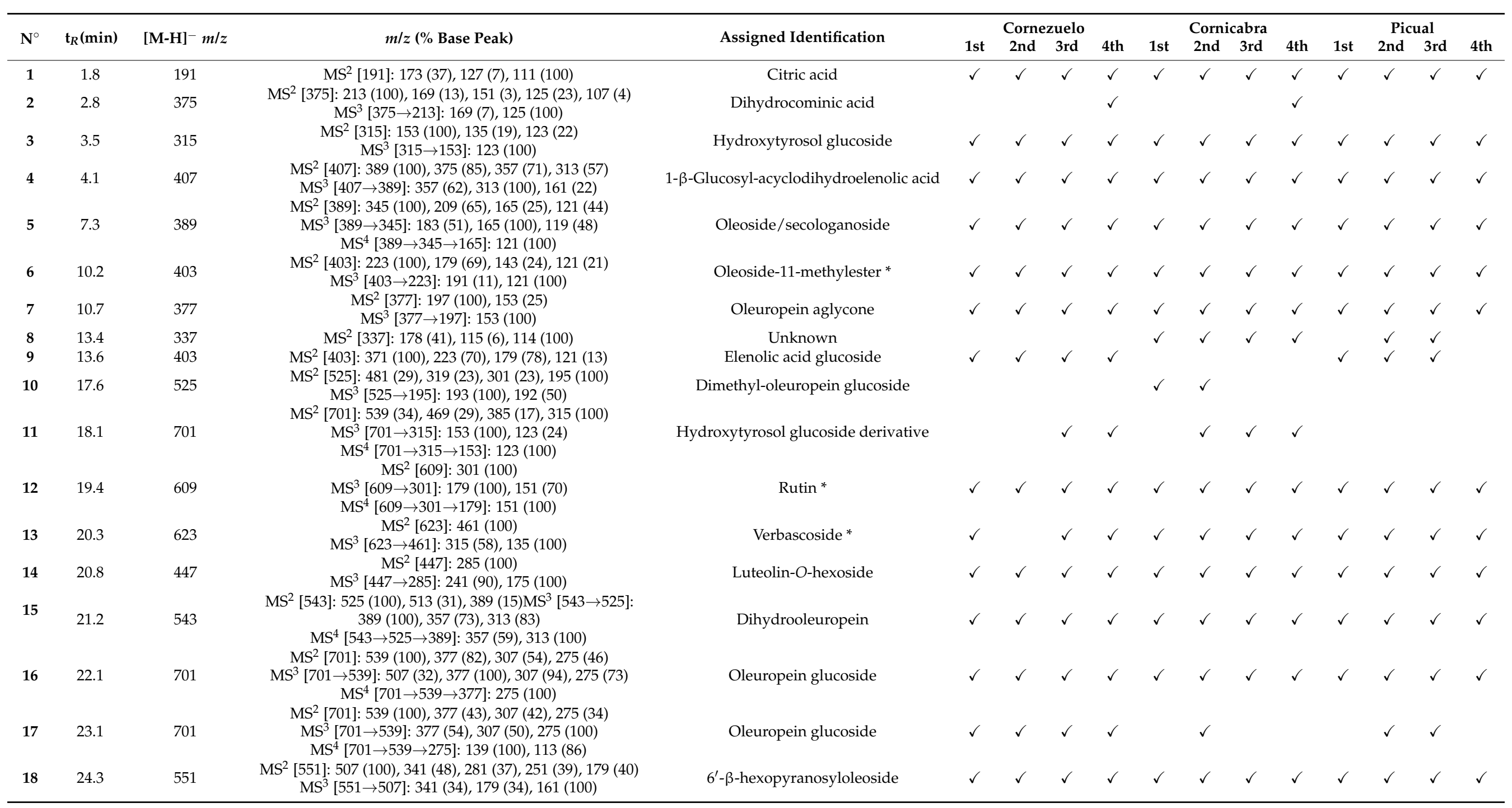


Table 1. Cont.

\begin{tabular}{|c|c|c|c|c|c|c|c|c|c|c|c|c|c|c|c|c|}
\hline \multirow{2}{*}{$\mathbf{N}^{\circ}$} & \multirow{2}{*}{$\mathbf{t}_{R}(\min )$} & \multirow{2}{*}[\mathrm{M}-\mathrm{H}]{$^{-} m / z$} & \multirow{2}{*}{$m / z$ (\% Base Peak) } & \multirow{2}{*}{ Assigned Identification } & \multicolumn{4}{|c|}{ Cornezuelo } & \multicolumn{4}{|c|}{ Cornicabra } & \multicolumn{4}{|c|}{ Picual } \\
\hline & & & & & 1st & 2nd & 3rd & 4th & 1st & 2nd & 3rd & 4th & 1st & 2nd & 3rd & 4th \\
\hline 19 & 25.4 & 377 & $\begin{array}{c}\mathrm{MS}^{2} \text { [377]: } 307 \text { (100), } 275 \text { (72) } \\
\mathrm{MS}^{3}[377 \rightarrow 307]: 275 \text { (100), } 139(22) \\
\mathrm{MS}^{4}[377 \rightarrow 307 \rightarrow 275]: 113(100)\end{array}$ & Oleuropein aglycone & & & & & & $\checkmark$ & $\checkmark$ & & & $\checkmark$ & $\checkmark$ & \\
\hline 20 & 26.0 & 569 & $\begin{array}{c}\mathrm{MS}^{2}[569]: 537(90), 403(100), 223(25) \\
\mathrm{MS}^{3}[569 \rightarrow 403]: 371(10), 223(100), 179(81), 143(28) \\
\mathrm{MS}^{4}[569 \rightarrow 403 \rightarrow 223]: 121(100), 101(24) \\
\mathrm{MS}^{2}[539]: 377(100), 307(57), 275(72)\end{array}$ & Elenolic acid glucoside derivative & & & & $\checkmark$ & & & $\checkmark$ & $\checkmark$ & & & $\checkmark$ & \\
\hline 21 & 27.0 & 539 & $\begin{array}{c}\left.\text { MS }^{3} \text { [539 } \rightarrow 377\right]: 307(100), 275(87), 149(8) \\
\left.\text { MS }^{4} \text { [539 } \rightarrow 377 \rightarrow 307\right]: 275(100)\end{array}$ & Oleuropein * & $\checkmark$ & $\checkmark$ & $\checkmark$ & $\checkmark$ & $\checkmark$ & $\checkmark$ & $\checkmark$ & $\checkmark$ & $\checkmark$ & $\checkmark$ & $\checkmark$ & $\checkmark$ \\
\hline 22 & 28.3 & 535 & $\begin{array}{c}\mathrm{MS}^{2} \text { [535]: } 491 \text { (100), } 265(36), 235(28) \\
\left.\operatorname{MS}^{3} \text { [535 } \rightarrow 491\right]: 345 \text { (46), } 265(46), 145(100)\end{array}$ & Comselogoside isomer & $\checkmark$ & $\checkmark$ & $\checkmark$ & $\checkmark$ & $\checkmark$ & $\checkmark$ & $\checkmark$ & $\checkmark$ & $\checkmark$ & $\checkmark$ & $\checkmark$ & $\checkmark$ \\
\hline 23 & 29.4 & 539 & $\begin{array}{c}\text { MS }^{2} \text { [539]: } 377 \text { (71), } 307(85), 275(100) \\
\text { MS }^{2} \text { [535]: } 491 \text { (100), } 265(60), 235(44), 209(37)\end{array}$ & Oleuropein isomer & $\checkmark$ & $\checkmark$ & $\checkmark$ & $\checkmark$ & $\checkmark$ & $\checkmark$ & $\checkmark$ & $\checkmark$ & $\checkmark$ & $\checkmark$ & $\checkmark$ & $\checkmark$ \\
\hline 24 & 30.1 & 535 & $\begin{array}{c}\text { MS }^{3}[535 \rightarrow 491]: 345(25), 235(46), 206(19), 145(100) \\
\text { MS }^{4}[535 \rightarrow 491 \rightarrow 145]: 143(100)\end{array}$ & Comselogoside isomer & $\checkmark$ & $\checkmark$ & $\checkmark$ & $\checkmark$ & & $\checkmark$ & $\checkmark$ & $\checkmark$ & $\checkmark$ & & & \\
\hline 25 & 30.6 & 473 & $\begin{array}{c}\mathrm{MS}^{2} \text { [473]: } 358 \text { (29), } 195 \text { (100), } 178 \text { (7) } \\
\left.\text { MS }^{3} \text { [473 } \rightarrow 195\right]: 135(100)\end{array}$ & Unknown & $\checkmark$ & $\checkmark$ & $\checkmark$ & & $\checkmark$ & $\checkmark$ & $\checkmark$ & $\checkmark$ & $\checkmark$ & $\checkmark$ & $\checkmark$ & \\
\hline 26 & 32.2 & 523 & $\begin{array}{c}\mathrm{MS}^{2} \text { [523]: } 361 \text { (100), } 291 \text { (59), } 259 \text { (47) } \\
\left.\text { MS }^{3} \text { [523 } \rightarrow 361\right]: 291 \text { (100), } 259 \text { (77), } 223 \text { (12) }\end{array}$ & Ligstroside & $\checkmark$ & $\checkmark$ & $\checkmark$ & $\checkmark$ & $\checkmark$ & $\checkmark$ & $\checkmark$ & $\checkmark$ & $\checkmark$ & $\checkmark$ & $\checkmark$ & $\checkmark$ \\
\hline
\end{tabular}

* Identified with analytical standard. 
Table 2. Quantification of phenolic compounds in olive fruits (cv. Cornezuelo) at different harvest times and harvest seasons.

\begin{tabular}{|c|c|c|c|c|c|c|c|c|}
\hline \multirow{2}{*}{\multicolumn{2}{|c|}{ Cornezuelo }} & \multicolumn{3}{|c|}{$2017 / 2018$} & \multicolumn{4}{|c|}{$2018 / 2019$} \\
\hline & & 2nd HD & 3rd HD & 4th HD & 1st HD & 2nd HD & 3rd HD & 4th HD \\
\hline & MI & 2 & 3.5 & 4 & 1 & 1.5 & 3 & 4 \\
\hline \multicolumn{9}{|c|}{ (Seco)iridoids } \\
\hline 5 & Oleoside/secologanoside & $20 \pm 2^{b}$ & $26 \pm 3^{b}$ & $100 \pm 10^{\mathrm{a}}$ & $25 \pm 3^{c}$ & $38.4 \pm 0.3^{c}$ & $102 \pm 5^{b}$ & $220 \pm 20^{a}$ \\
\hline 6 & Oleoside-11-methylester & $0.48 \pm 0.03^{b}$ & $6.1 \pm 0.5^{b}$ & $65 \pm 6^{\mathrm{a}}$ & $12.3 \pm 0.7^{\mathrm{d}}$ & $22 \pm 2^{c}$ & $70 \pm 2^{b}$ & $128 \pm 5^{\mathrm{a}}$ \\
\hline 7 & Oleuropein aglycone & $3.62 \pm 0.08$ & $4.0 \pm 0.5$ & - & $2.2 \pm 0.1^{b}$ & $2.4 \pm 0.1^{b}$ & $6.3 \pm 0.1^{\mathrm{a}}$ & - \\
\hline 9 & Elenolic acid glucoside & $11 \pm 2^{b}$ & $7.8 \pm 0.5^{\mathrm{b}}$ & $47 \pm 1^{\mathrm{a}}$ & $16 \pm 2^{c}$ & $14.19 \pm 0.05^{c}$ & $69 \pm 5^{b}$ & $88 \pm 7^{\mathrm{a}}$ \\
\hline 16 & Oleuropein glucoside & $7.8 \pm 0.3^{b}$ & $11.4 \pm 0.2^{\mathrm{a}}$ & $6.8 \pm 0.7^{b}$ & $6.3 \pm 0.7^{b}$ & $6.5 \pm 0.3^{b}$ & $9.2 \pm 0.9^{\mathrm{a}}$ & $7.7 \pm 0.3^{\mathrm{ab}}$ \\
\hline 17 & Oleuropein glucoside & $2.3 \pm 0.3^{c}$ & $4.0 \pm 0.4^{\mathrm{b}}$ & $9.3 \pm 0.9^{a}$ & $2.63 \pm 0.01^{\mathrm{c}}$ & - & $11.7 \pm 0.6^{b}$ & $14 \pm 1^{\mathrm{a}}$ \\
\hline 18 & $6^{\prime}$ - $\beta$-hexopyranosyloleoside & $35 \pm 3^{\mathrm{ab}}$ & $39 \pm 4^{\mathrm{a}}$ & $30.8 \pm 0.3^{b}$ & $30 \pm 3^{a}$ & $32.5 \pm 0.4^{\mathrm{a}}$ & $32 \pm 2^{a}$ & $32 \pm 1^{a}$ \\
\hline 20 & Elenolic acid glucoside derivative & - & $3.6 \pm 0.1$ & $24 \pm 2$ & - & - & - & $13.2 \pm 0.6$ \\
\hline 21 & Oleuropein & $24 \pm 1^{\mathrm{c}}$ & $60 \pm 3^{b}$ & $88 \pm 5^{a}$ & $61 \pm 5^{c}$ & $78 \pm 6^{c}$ & $131 \pm 8^{b}$ & $160 \pm 10^{\mathrm{a}}$ \\
\hline 22 & Comselogoside isomer & $99 \pm 8^{a b}$ & $110 \pm 10^{\mathrm{a}}$ & $81.9 \pm 0.6^{b}$ & $62 \pm 5^{b c}$ & $64.7 \pm 0.1^{\mathrm{ab}}$ & $70 \pm 1^{a}$ & $55 \pm 2^{c}$ \\
\hline 23 & Oleuropein isomer & $37 \pm 4$ & $42 \pm 4$ & $30.3 \pm 0.2$ & $34 \pm 3^{a}$ & $38 \pm 2^{a}$ & $35 \pm 1^{a}$ & $28 \pm 2^{b}$ \\
\hline 24 & Comselogoside isomer & $5.6 \pm 0.6^{b}$ & $11 \pm 1^{\mathrm{a}}$ & $9.4 \pm 0.9^{\mathrm{a}}$ & $5.3 \pm 0.6^{b}$ & $5.0 \pm 0.2^{b}$ & $5.1 \pm 0.1^{b}$ & $6.4 \pm 0.3^{\mathrm{a}}$ \\
\hline 26 & Ligstroside & $2.7 \pm 0.3^{b}$ & $6.6 \pm 0.7^{\mathrm{a}}$ & $7.2 \pm 0.8^{a}$ & $7.9 \pm 0.9^{b}$ & $7.6 \pm 0.6^{b}$ & $19 \pm 2^{a}$ & $10 \pm 1^{b}$ \\
\hline Total & & $270 \pm 10^{\mathrm{c}}$ & $340 \pm 10^{b}$ & $510 \pm 10^{a}$ & $278 \pm 9^{d}$ & $322 \pm 7^{c}$ & $580 \pm 10^{b}$ & $780 \pm 20^{a}$ \\
\hline \multicolumn{9}{|c|}{ Other compounds } \\
\hline 3 & Hydroxytyrosol glucoside & $2.4 \pm 0.3^{c}$ & $12 \pm 1^{b}$ & $30 \pm 3^{a}$ & $3.15 \pm 0.05^{\mathrm{d}}$ & $6.5 \pm 0.4^{c}$ & $10.8 \pm 0.7^{b}$ & $35.9 \pm 0.9^{\mathrm{a}}$ \\
\hline 11 & Hydroxytyrosol glucoside derivative & - & $3.9 \pm 0.4$ & $9.5 \pm 0.2$ & - & - & $4.6 \pm 0.4$ & $12.2 \pm 0.6$ \\
\hline 12 & Rutin & $19 \pm 1^{a}$ & $17 \pm 2^{a}$ & $5.7 \pm 0.5^{b}$ & $4.5 \pm 0.5^{b}$ & $4.7 \pm 0.5^{b}$ & $10.9 \pm 0.9^{\mathrm{a}}$ & $3.3 \pm 0.3^{b}$ \\
\hline 13 & Verbascoside & $0.026 \pm 0.002^{c}$ & $0.26 \pm 0.03^{b}$ & $2.47 \pm 0.01^{\mathrm{a}}$ & $0.040 \pm 0.003^{c}$ & - & $2.38 \pm 0.08^{b}$ & $6.39 \pm 0.09^{a}$ \\
\hline 14 & Luteolin-O-hexoside & $10.9 \pm 0.6^{b}$ & $18 \pm 2^{a}$ & $10.7 \pm 0.1^{\mathrm{b}}$ & - & $1.5 \pm 0.1^{\mathrm{c}}$ & $9.2 \pm 0.8^{\mathrm{a}}$ & $6.9 \pm 0.5^{b}$ \\
\hline Total & & $32 \pm 1^{\mathrm{c}}$ & $51 \pm 3^{b}$ & $58 \pm 3^{a}$ & $7.7 \pm 0.5^{\mathrm{d}}$ & $12.7 \pm 0.6^{c}$ & $38 \pm 1^{b}$ & $65 \pm 1^{\mathrm{a}}$ \\
\hline TIPC & & $300 \pm 10^{c}$ & $390 \pm 10^{b}$ & $570 \pm 10^{a}$ & $286 \pm 9^{d}$ & $335 \pm 7^{c}$ & $620 \pm 10^{b}$ & $840 \pm 20^{a}$ \\
\hline
\end{tabular}

Values (mg/100 g fresh weight) are mean \pm SD of three parallel measurements. Different superscripts $\left({ }^{\mathrm{a}},{ }^{\mathrm{b}},{ }^{\mathrm{c}}\right.$ and $\left.{ }^{\mathrm{d}}\right)$ indicate significant differences in the extracts $(p<0.05)$. MI: Maturity Index. 
Table 3. Quantification of phenolic compounds in olive fruits (cv. Cornicabra) at different harvest times and harvest seasons.

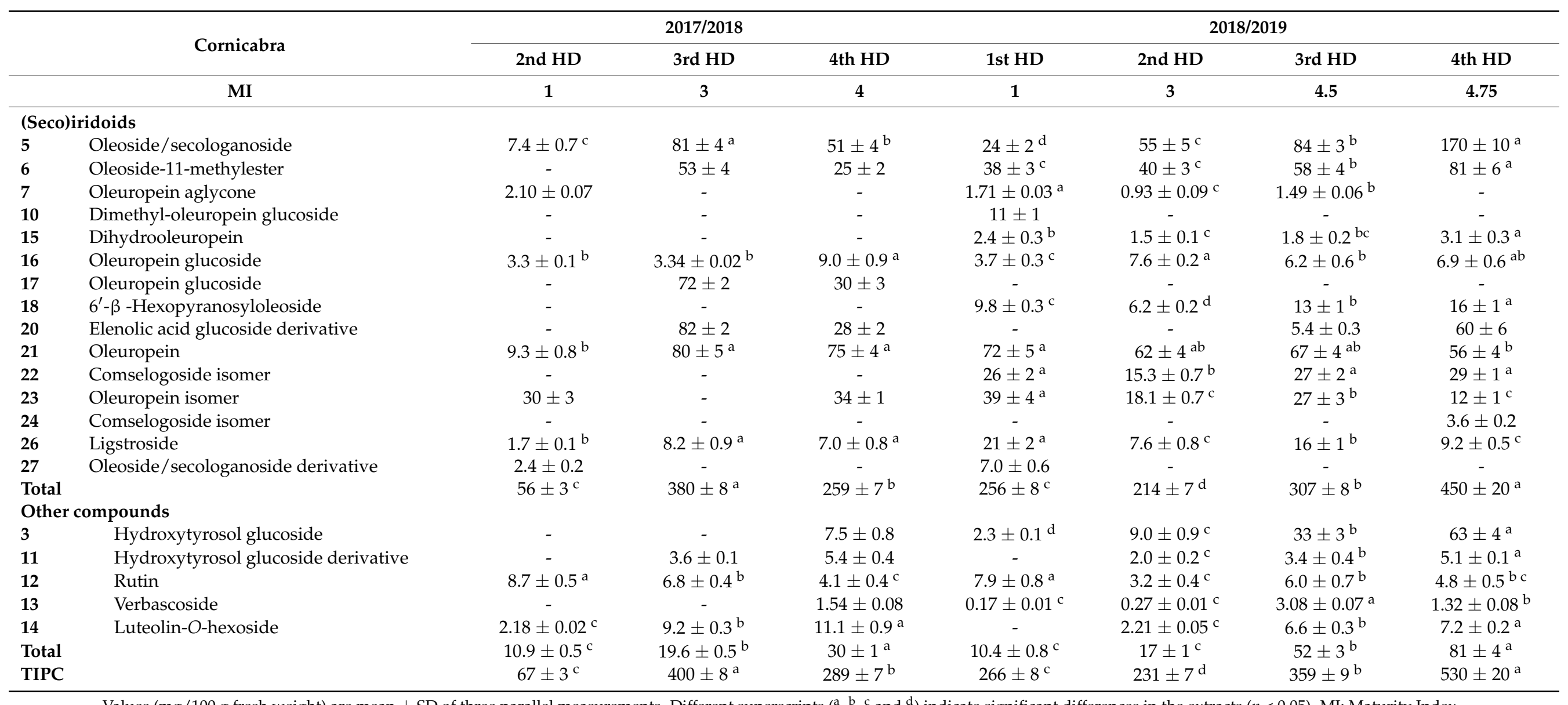

Values (mg/100 g fresh weight) are mean \pm SD of three parallel measurements. Different superscripts $\left({ }^{\mathrm{a}},{ }^{\mathrm{b}},{ }^{\mathrm{c}}\right.$ and $\left.{ }^{\mathrm{d}}\right)$ indicate significant differences in the extracts $(p<0.05)$. MI: Maturity Index. 
Table 4. Quantification of phenolic compounds in olive fruits (cv. Picual) at different harvest times and harvest seasons.

\begin{tabular}{|c|c|c|c|c|c|c|c|c|}
\hline & \multirow{2}{*}{ Picual } & \multicolumn{3}{|c|}{$2017 / 2018$} & \multicolumn{4}{|c|}{$2018 / 2019$} \\
\hline & & 2nd HD & 3rd HD & 4th HD & 1st HD & 2nd HD & 3rd HD & 4th HD \\
\hline & MI & 2 & 3.75 & 4.25 & 1 & 2.75 & 5 & 5.75 \\
\hline \multicolumn{9}{|c|}{ (Seco)iridoids } \\
\hline 5 & Oleoside/secologanoside & - & $8.8 \pm 0.8$ & $25.1 \pm 6$ & $38 \pm 4^{c}$ & $36.6 \pm 0.4^{\mathrm{c}}$ & $74 \pm 7^{b}$ & $100 \pm 10^{a}$ \\
\hline 6 & Oleoside-11-methylester & - & $1.4 \pm 0.2$ & $10.9 \pm 0.9$ & $29 \pm 3^{b}$ & $27 \pm 2^{b}$ & $54 \pm 4^{\mathrm{a}}$ & $56 \pm 4^{\mathrm{a}}$ \\
\hline 7 & Oleuropein aglycone & $2.2 \pm 0.1^{b}$ & $3.1 \pm 0.5^{\mathrm{a}}$ & $2.6 \pm 0.3^{\mathrm{ab}}$ & $3.7 \pm 0.4^{b}$ & $3.5 \pm 0.1^{b}$ & $6.0 \pm 0.5^{\mathrm{a}}$ & $4.02 \pm 0.04^{b}$ \\
\hline 9 & Elenolic acid glucoside & - & - & - & $10.3 \pm 0.2$ & - & - & - \\
\hline 16 & Oleuropein glucoside & $4.5 \pm 0.6^{\mathrm{b}}$ & $3.0 \pm 0.4^{b}$ & $9.3 \pm 0.9^{\mathrm{a}}$ & $5.0 \pm 0.4^{b}$ & $6.4 \pm 0.7^{\mathrm{ab}}$ & $7.5 \pm 0.7^{\mathrm{a}}$ & $7.7 \pm 0.2^{\mathrm{a}}$ \\
\hline 17 & Oleuropein glucoside & $2.5 \pm 0.3^{a}$ & $2.5 \pm 0.3^{\mathrm{a}}$ & $2.0 \pm 0.1^{\mathrm{a}}$ & - & - & $4.0 \pm 0.4$ & - \\
\hline 18 & 6 - $\beta$-hexopyranosyloleoside & $23 \pm 1^{b}$ & $30 \pm 3^{\mathrm{a}}$ & $25 \pm 1^{b}$ & $31.9 \pm 0.2^{b}$ & $32 \pm 3^{b}$ & $41 \pm 1^{\mathrm{a}}$ & $40 \pm 2^{a}$ \\
\hline 20 & Elenolic acid glucoside derivative & - & $21.1 \pm 0.5$ & $15.4 \pm 0.6$ & - & - & $12 \pm 1$ & - \\
\hline 21 & Oleuropein & $13.1 \pm 0.8^{\mathrm{c}}$ & $16.5 \pm 0.9^{b}$ & $44 \pm 2^{\mathrm{a}}$ & $107 \pm 5^{c}$ & $85 \pm 5^{d}$ & $191 \pm 9^{a}$ & $152 \pm 7^{b}$ \\
\hline 22 & Comselogoside isomer & $42 \pm 4^{\mathrm{ab}}$ & $46 \pm 4^{\mathrm{a}}$ & $37 \pm 2^{b}$ & $42.4 \pm 0.7^{\mathrm{b}}$ & $46 \pm 3^{b}$ & $53 \pm 2^{a}$ & $45 \pm 3^{b}$ \\
\hline 23 & Oleuropein isomer & - & - & - & $52 \pm 5^{c}$ & $91 \pm 9^{b}$ & $86 \pm 8^{b}$ & $114 \pm 3^{\mathrm{a}}$ \\
\hline 24 & Comselogoside isomer & $3.5 \pm 0.4^{\mathrm{a}}$ & $3.7 \pm 0.4^{\mathrm{a}}$ & $4.4 \pm 0.5^{\mathrm{a}}$ & $2.6 \pm 0.3$ & - & - & - \\
\hline 26 & Ligstroside & - & - & $2.6 \pm 0.3$ & $17 \pm 2^{b}$ & $11 \pm 1^{\mathrm{c}}$ & $23 \pm 2^{a}$ & $19 \pm 2^{a b}$ \\
\hline Tota & & $97 \pm 4^{c}$ & $142 \pm 5^{b}$ & $184 \pm 7^{\mathrm{a}}$ & $352 \pm 9^{b}$ & $350 \pm 10^{\mathrm{b}}$ & $570 \pm 20^{\mathrm{a}}$ & $550 \pm 10^{\mathrm{a}}$ \\
\hline \multicolumn{9}{|c|}{ Other compounds } \\
\hline 3 & Hydroxytyrosol glucoside & $9.3 \pm 0.8^{a}$ & $11 \pm 1^{\mathrm{a}}$ & $10.5 \pm 0.6^{\mathrm{a}}$ & $20 \pm 2^{b}$ & $14 \pm 1^{\mathrm{c}}$ & $21 \pm 2^{b}$ & $31 \pm 2^{a}$ \\
\hline 12 & Rutin & $8.3 \pm 0.2^{b}$ & $8.0 \pm 0.3^{b}$ & $10.3 \pm 0.5^{\mathrm{a}}$ & $7.9 \pm 0.8^{c}$ & $9.2 \pm 0.9^{c}$ & $32 \pm 3^{a}$ & $16.5 \pm 0.2^{b}$ \\
\hline 13 & Verbascoside & $26 \pm 1^{\mathrm{a}}$ & $23 \pm 1^{b}$ & $17 \pm 1^{\mathrm{c}}$ & $9.2 \pm 0.8^{b}$ & $5.8 \pm 0.4^{c}$ & $10.1 \pm 0.8^{b}$ & $17.8 \pm 0.8^{\mathrm{a}}$ \\
\hline 14 & Luteolin-O-hexoside & $4.9 \pm 0.3^{c}$ & $20 \pm 1^{b}$ & $37 \pm 1^{\mathrm{a}}$ & $2.9 \pm 0.3^{\mathrm{d}}$ & $11 \pm 1^{\mathrm{c}}$ & $37 \pm 4^{\mathrm{a}}$ & $25 \pm 2^{b}$ \\
\hline Tota & & $49 \pm 1^{\mathrm{c}}$ & $62 \pm 2^{b}$ & $75 \pm 2^{a}$ & $40 \pm 2^{c}$ & $40 \pm 2^{c}$ & $100 \pm 5^{a}$ & $90 \pm 3^{b}$ \\
\hline TIP & & $146 \pm 4^{\mathrm{c}}$ & $204 \pm 5^{b}$ & $259 \pm 7^{\mathrm{a}}$ & $392 \pm 9^{b}$ & $390 \pm 10^{b}$ & $670 \pm 20^{\mathrm{a}}$ & $640 \pm 10^{\mathrm{a}}$ \\
\hline
\end{tabular}

Values (mg/100 g fresh weight) are mean \pm SD of three parallel measurements. Different superscripts $\left({ }^{\mathrm{a}}, \mathrm{b},{ }^{\mathrm{c}}\right.$ and $\left.{ }^{\mathrm{d}}\right)$ indicate significant differences in the extracts $(p<0.05)$. MI: Maturity Index. 
Phenolic compounds were extracted using a previous procedure [20] with modifications. An amount of $2 \mathrm{~g}$ of olives (pitted and crushed) was extracted with $30 \mathrm{~mL}$ of $\mathrm{MeOH}: \mathrm{H}_{2} \mathrm{O}(80: 20, v / v)$ for $10 \mathrm{~min}$ using an ultrasonic liquid processor at $50 \%$ power (Qsonica Sonicators; Newton, CT, USA; $55 \mathrm{~W}$ power and $20 \mathrm{kHz}$ frequency). After centrifugation at $1.800 \mathrm{~g}$ for $15 \mathrm{~min}$, solutions were filtered (Whatman No.1 filters). Solutions were subjected to clean-up with $40 \mathrm{~mL}$ of $\mathrm{n}$-hexane (twice). The solvent was evaporated under reduced pressure and dried extracts (DE) were stored at $-20^{\circ} \mathrm{C}$. Extractions were performed in triplicate for each sample.

\subsection{HPLC Analysis of the Phenolic Compounds}

All chromatographic conditions are given in Supplementary Material.

\subsection{ICP-MS Analysis of Olives}

The characteristics of the equipment, operating conditions and validation of ICP-MS method are included in Supplementary Material (Tables S1-S3 and Figure S1).

Sample digestion was performed with a MARSXpress microwave digestion system (CEM; Gilson; Madrid, Spain) with $50 \mathrm{~mL}$ PFA vessels. The following procedure was used (in triplicate for each sample): $0.25 \mathrm{~g}$ of sample (pitted and homogenized), $7 \mathrm{~mL} \mathrm{HNO}_{3}$ and $3 \mathrm{~mL} \mathrm{H}_{2} \mathrm{O}_{2}$ were added to a digestion vessel. After $10 \mathrm{~min}$ at room temperature, samples were digested as detailed in Supplementary Material in Table S4. Then, the solutions were diluted to $50 \mathrm{~mL}$ with ultrapure water in metal-free ICP-MS vials.

Calibration curves were prepared at six concentrations in $5 \%(v / v)$ sub-boiling $\mathrm{HNO}_{3}$. The ICP-MS instrument added internal standards automatically.

\subsection{Statistical Analysis}

SPSS Statistics software v.22 (IBM SPSS Statistics for Windows, IBM Corp., Armonk, NY, USA) was used. Data are expressed as mean \pm standard deviation (three replicates). A one-way analysis of variance (ANOVA) with Tukey's HSD post-hoc test $(p<0.05)$ was done.

\section{Results and Discussion}

\subsection{HPLC-MS Analysis}

Initially, for the 2017/2018 season, the months of November, December and January were selected to analyse the olive fruits, as they are the typical months during which farmers usually harvest them. The phenolic contents obtained in this harvest were low compared to previously reported ones [10]. This could be due to the low olive production and low fat content in the 2017/2018 harvest, probably caused by the weather conditions (rain precipitations in the months previous to the 2017/2018 harvesting were approximately $50 \%$ of those in the following season). Therefore, two objectives were proposed to improve this study: to repeat the analyses for season 2018/2019; and to analyse olive fruits also in October (due to the recommendation of several experts regarding early harvesting of fruits to improve olive oil characteristics).

From a qualitative point of view, the base peak chromatograms of the three olive fruit varieties (season 2018/2019, 4th HD) showed similar profiles (Figure 1). Chromatograms comparing the 1st HD and 4th HD (October and January, respectively) of each olive variety (Cornezuelo, Cornicabra and Picual) for the 2018/2019 season are shown in Figure 2. A total of 25 phytochemicals, almost 70\% secoiridoids, were identified or putatively characterized. The characterization was done by using analytical standards and bibliographic information. Compounds were numbered according to their order of elution, keeping the same numeration in all samples. Mass spectrometry data are given in Table 1 for the compounds identified in season 2018/2019 (similar results were obtained in season $2017 / 2018$ for the same HD). 


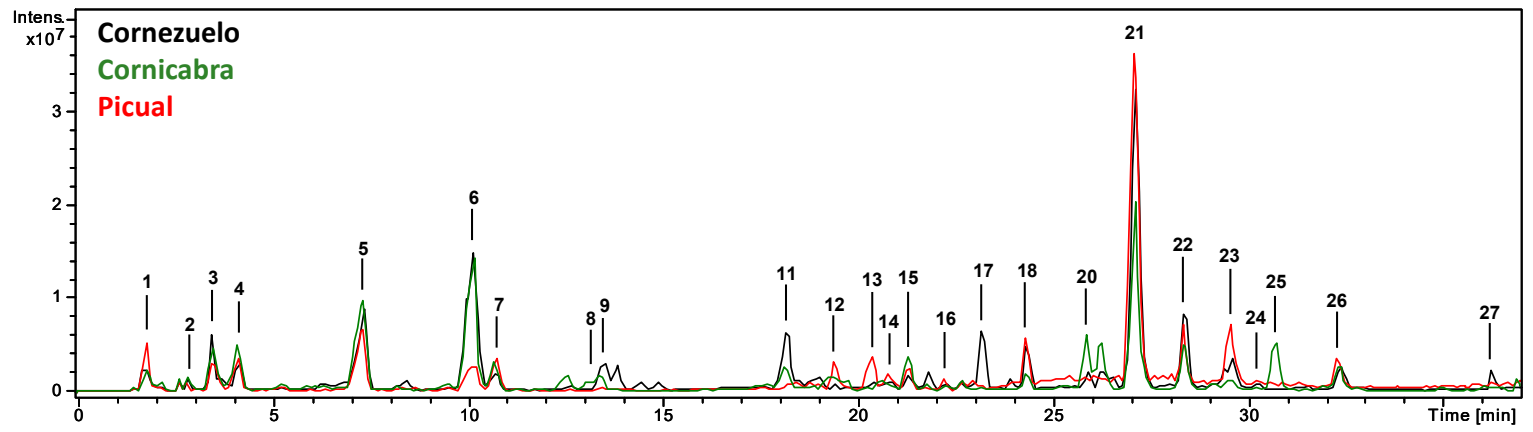

Figure 1. HPLC-ESI/MS ${ }^{n}$ base peak chromatograms (BPC) of the extracts of Cornezuelo, Cornicabra and Picual olives for 2018/2019 season in 4th HD.
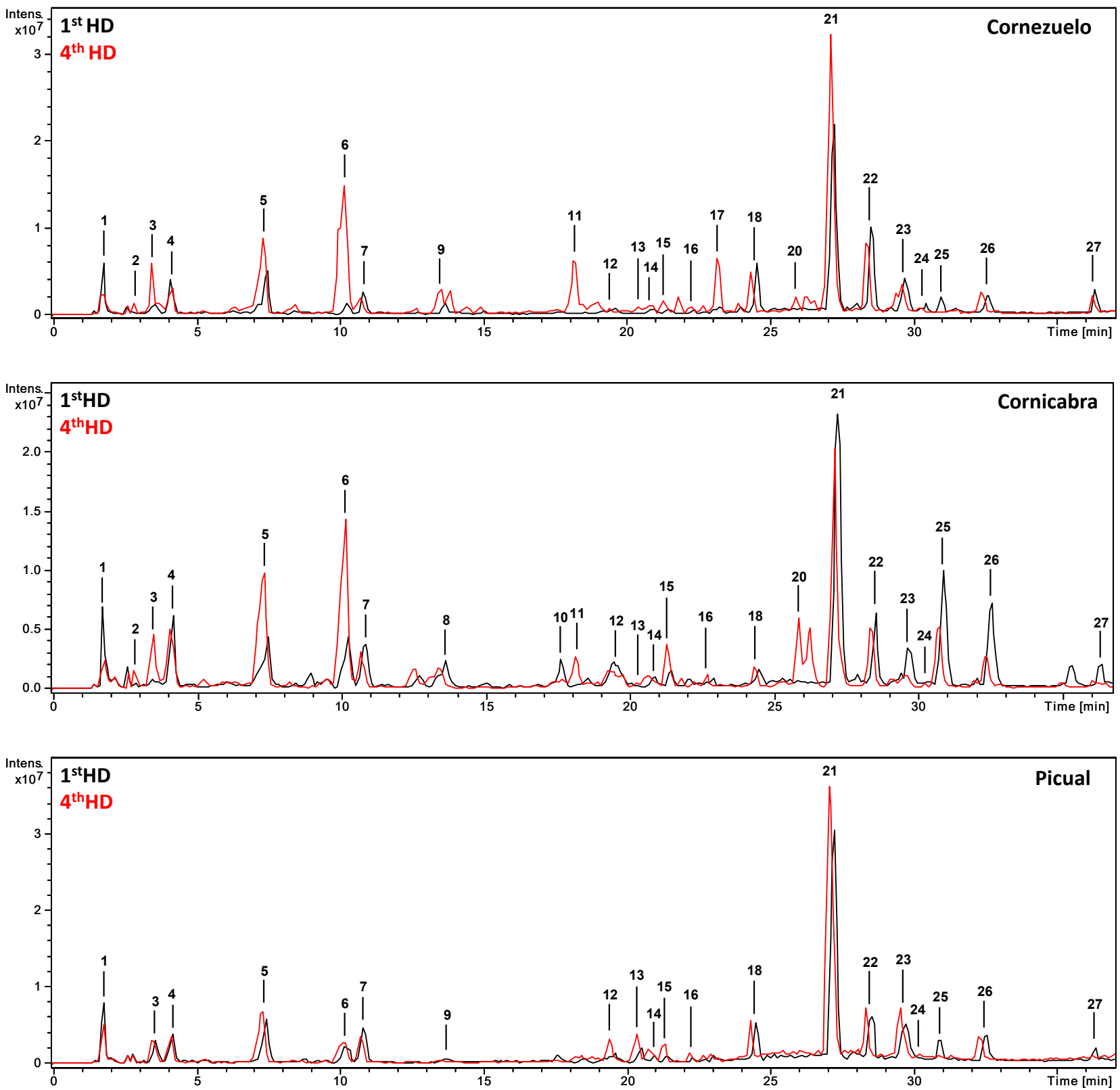

Figure 2. HPLC-ESI/MSn base peak chromatograms (BPC) of the extracts of Cornezuelo, Cornicabra and Picual olives in 1st HD and 4th HD (2018/2019 season). 


\subsubsection{Secoiridoids}

Compound 4 showed $[\mathrm{M}-\mathrm{H}]^{-}$at $m / z 407$ and its fragmentation pattern was in agreement with 1- $\beta$-glucosyl-acyclodihydroelenolic acid [21].

Compounds 5, 6, 18, and 27 were oleoside derivatives. Compound 5 presented $[\mathrm{M}-\mathrm{H}]^{-}$ ion at $m / z 389$ and suffered the loss of $44 \mathrm{Da}$ (carbon dioxide molecule) to yield the base peak at $m / z 345$; it was tentatively characterized as oleoside/secologanoside [22]. Compound 6 was characterized as oleoside-11-methylester with an analytical standard. Compound 18 was another oleoside, $6^{\prime}-\beta$-hexopyranosyloleoside, based on its $[\mathrm{M}-\mathrm{H}]^{-}$ion at $m / z 551$, $\mathrm{MS}^{2}$ base peak at $m / z 507$, and $\mathrm{MS}^{3}$ base peak at $m / z 161$ [23]. According to bibliographic data, compound 27, with deprotonated molecular ion at $\mathrm{m} / \mathrm{z} 557$, $\mathrm{MS}^{2}$ base peak at $\mathrm{m} / \mathrm{z}$ 513 , and $\mathrm{MS}^{3}$ at $m / z$ 345, was tentatively characterized as an oleoside/secologanoside derivative [23].

Compounds 7, 10, 15, 16, 17, 19, 21 and 23 were oleuropein derivatives. Compounds 7 and 19 , with [M-H] $]^{-}$at $m / z 377$, were identified as oleuropein aglycone isomers [24,25]. Based on the presence of a deprotonated molecular ion at $\mathrm{m} / \mathrm{z} 525$ and fragment ions at $\mathrm{m} / \mathrm{z}$ 481, 389, 209 and 195, compound 10 was tentatively characterized as dimethyl-oleuropein glucoside [26]. Compound 15 was identified as dihydrooleuropein; it showed $[\mathrm{M}-\mathrm{H}]^{-}$ at $m / z 543$ and main fragment ions at $m / z 525$ and $m / z 513$ [27]. With [M-H] ${ }^{-}$at $m / z$ 701, compounds 16 and 17 were identified as oleuropein glucoside isomers. Their MS $^{2}$ fragmentation profiles produced main fragment ions at $m / z 539$, due to the neutral loss of a hexose (162 Da), and the typical fragmentation of oleuropein $(\mathrm{m} / \mathrm{z}$ at 377,307 , and 275$)$ was observed [22]. Oleuropein (compound 21) was one of the most abundant compounds and was identified by comparison with an analytical standard, observing characteristic fragments at $\mathrm{m} / \mathrm{z} 377,307$ and 275 [25]. Compound 23 presented the same [M-H] ${ }^{-}$and similar fragmentation pattern than oleuropein, so it was tentatively characterized as an isomer.

Compound 9 exhibited $[\mathrm{M}-\mathrm{H}]^{-}$at $\mathrm{m} / \mathrm{z} 403$ and was characterized as elenolic acid glucoside based on the fragment ions at $\mathrm{m} / \mathrm{z} 371,223$ and 179, corresponding to neutral losses of $32 \mathrm{Da}$ (methyl group), $180 \mathrm{Da}$ (hexose) and $44 \mathrm{Da}$ (carbon dioxide), respectively [28]. Compound 20 presented a fragmentation pattern similar to compound 9 , so it was characterized as an elenolic acid derivative.

Compounds 22 and 24 exhibited deprotonated molecular ions at $m / z 535$, base peak at $m / z$ 491, and fragmentation patterns typical of comselogoside [29].

Compound 26 was characterized as ligstroside due to the $[\mathrm{M}-\mathrm{H}]^{-}$at $m / z 523$, neutral loss of $162 \mathrm{Da}$ (hexoside) to yield the base peak at $m / z 361$, and main fragment ions in $\mathrm{MS}^{3}$ at $m / z 291$ and 259 [22].

\subsubsection{Other Compounds}

Compound 1, with deprotonated molecular ion at $\mathrm{m} / \mathrm{z} 191$ and characteristic fragment ions at $m / z 173$ and 111, was identified as citric acid [30].

Compound 2, with $[\mathrm{M}-\mathrm{H}]^{-}$at $\mathrm{m} / \mathrm{z} 375$, was characterized as dihydrocominic acid considering bibliographic information [31].

Compound 3 was identified as hydroxytyrosol glucoside. It presented $[\mathrm{M}-\mathrm{H}]^{-}$ion at $m / z 315$, fragment ion at $m / z 153$ (from the neutral loss of $162 \mathrm{Da}$, hexoside) and a typical fragment ion at $m / z 123$ [32]. With [M-H] $]^{-}$ion at $m / z 701$ and the same fragmentation pattern that hydroxytyrosol glucoside, compound 11 was tentatively characterized as a derivative.

Compound 12 , with $[\mathrm{M}-\mathrm{H}]^{-}$at $m / z 609$, was identified as rutin by comparison with an analytical standard.

Compound 13 was identified as verbascoside. It showed $[\mathrm{M}-\mathrm{H}]^{-}$ion at $m / z 623$ and characteristic fragments at $m / z 461$ (neutral loss of $162 \mathrm{Da}$, hexoside), $m / z 315$ (neutral loss of $146 \mathrm{Da}$, rhamnoside) and $\mathrm{m} / z 135$. The identification was confirmed with an analytical standard.

Compound 14 was identified as luteolin-O-hexoside due to the neutral loss of $162 \mathrm{Da}$ to yield luteolin aglycone at $m / z 285$. 


\subsection{Quantification of Phenolic Compounds}

Twenty-one different compounds were quantified. The concentrations obtained for the three varieties of olive fruits, in the two different seasons, are given in Tables 2-4.

A similar pattern with regards to the main compounds, as well as the trend observed during the different harvesting dates, was observed in both harvesting seasons. However, the three fruit varieties presented higher concentration of phenolics in season 2018/2019. The lower phenolic content in season 2017/2018 may be due to two different issues: low fruit production and olive yield, along with a higher percentage of humidity, which has been previously related to lower phenolic concentrations [15]. All humidity percentages are shown in Table S5.

First of all, it can be observed that the Cornezuelo variety presented the highest TIPC (Total Individual Phenolic Content: sum of all the quantified phenolics), followed by the Picual and Cornicabra varieties. Secoiridoids accounted for approximately $90 \%$ of TIPC in the Cornezuelo and Cornicabra varieties in both harvesting seasons. In the Picual variety, secoiridoids accounted for $70-90 \%$ of TIPC, with differences depending on the harvest dates; the highest percentage was obtained in 2018/2019 crop season.

Figures 3 and 4 show heat maps highlighting the main compounds in each of the olive varieties during both harvesting seasons. The main secoiridoids in all samples were oleuropein and its isomer, oleoside/secologanoside, oleoside-11-methylester and comselogoside isomers. Oleuropein and its isomer (compounds 21 and 23) accounted for $20-40 \%, 20-50 \%$, and $10-50 \%$ of total compounds in the Cornezuelo, Cornicabra, and Picual varieties, respectively. A comselogoside isomer (compound 22) was most abundant in the Cornezuelo and Picual varieties (approximately 10-30\%) compared to Cornicabra (lower than $10 \%$ of total compounds). On the other hand, oleoside/secologanoside (compound 5) was more abundant in Cornicabra (10-30\%) than in Cornezuelo and Picual (Picual presented the lower percentage of this compound). In the Cornezuelo variety, the main secoiridoids mentioned represented approximately $70 \%$ of the total secoiridoids for both seasons, whereas in Cornicabra olive fruits they accounted for $80 \%$ of the total secoiridoids. In the Picual variety, the main secoiridoids showed wider variations $(60-80 \%$ of the total secoiridoids) than those observed in the other olive varieties studied.

Regarding the content of individual phenolics, the maximum values of oleuropein in seasons 2017/2018 and 2018/2019, respectively, were 88 and $160 \mathrm{mg} / 100 \mathrm{~g}$ fresh weight (FW) in Cornezuelo, 80 and 72 mg/100 g FW in Cornicabra, and 44 and $191 \mathrm{mg} / 100 \mathrm{~g} \mathrm{FW}$ in Picual. In previous studies in seven Spanish olive varieties, including Cornicabra and Picual, maximum oleuropein levels ranged between $178 \mathrm{mg} / 100 \mathrm{~g}$ and $1861 \mathrm{mg} / 100 \mathrm{~g}$ FW $[10,13,33]$. In other studies carried out in varieties from other countries, oleuropein levels similar to those obtained in this research were reported, such as $124-327 \mathrm{mg} / 100 \mathrm{~g}$ FW in the Portuguese Cobrançosa variety [34], 266-675 mg/100 g FW in the Tunisian olive varieties Dhokar, Chétoi and Chemlali [35,36] and 298 mg/100 g FW in the Turkish variety Sariulak [2]. These differences can be attributed not only to studies performed in other varieties, but also to changes in collection areas and climatological conditions. As can be observed by the results reported here, the specific season of olive harvesting is critical with respect to phenolic concentrations. Hence, a straightforward comparison of particular phenolic compounds is difficult to do between different studies.

For rutin, the maximum values obtained in our study ranged between $8.7 \mathrm{mg} / 100 \mathrm{~g}$ FW in Cornicabra and $32 \mathrm{mg} / 100 \mathrm{~g}$ FW in Picual. In a previous report, similar rutin values were observed: $24 \mathrm{mg} / 100 \mathrm{~g}$ FW in the Picolimón variety and $45 \mathrm{mg} / 100 \mathrm{~g}$ FW in Picual [10]. Similar values (17-54 mg/100 g FW) were reported in the Spanish varieties Arbequina and Royal $[13,33]$, as well as in the Turkish varieties Sariulak, Ayvalik and Gemlik [2,37]. 


\section{7/2018}

\section{№ Secoiridoids}

5 Oleoside/secologanoside

6 Oleoside-11-methylester

7 Oleuropein aglycone

9 Elenolic acid glucoside

10 Dimethyl-oleuropein glucoside

15 Dihydrooleuropein

16 Oleuropein glucoside

17 Oleuropein glucoside

18 6'- $\beta$-Hexopyranosyloleoside

20 Elenolic acid derivative

21 Oleuropein

22 Comselogoside isomer

23 Oleuropein isomer

24 Comselogoside isomer

26 Ligstroside

27 Oleoside/secologanoside derivative Other compounds

3 Hydroxytyrosol glucoside

11 Hydroxytyrosol glucoside derivative

12 Rutin

13 Verbascoside

14 Luteolin-O-hexoside

\begin{tabular}{|ccc}
$\mathbf{2}^{\text {nd }} \mathbf{H D}$ & $\begin{array}{c}\text { Cornezuelo } \\
\mathbf{3}^{\text {rd }} \mathbf{H D}\end{array}$ & $\mathbf{4}^{\text {th }} \mathbf{H D}$ \\
\hline $6.7 \pm 0.7$ & $6.5 \pm 0.7$ & $18 \pm 2$ \\
$0.16 \pm 0.01$ & $1.5 \pm 0.1$ & $11 \pm 1$ \\
$1.22 \pm 0.03$ & $1.0 \pm 0.1$ & 0 \\
$3.7 \pm 0.7$ & $1.9 \pm 0.7$ & $8.1 \pm 0.2$ \\
0 & 0 & 0 \\
0 & 0 & 0 \\
$2.6 \pm 0.1$ & $2.86 \pm 0.05$ & $1.2 \pm 0.1$ \\
$0.8 \pm 0.1$ & $1.0 \pm 0.1$ & $1.6 \pm 0.2$ \\
\hline $11.8 \pm 0.9$ & $9.8 \pm 0.9$ & $5.34 \pm 0.05$ \\
\hline 0 & $0.90 \pm 0.03$ & $4.2 \pm 0.3$ \\
\hline $8.1 \pm 0.3$ & $15.1 \pm 0.8$ & $15.3 \pm 0.9$ \\
\hline $33 \pm 3$ & $28 \pm 2$ & $14.2 \pm 0.1$ \\
\hline $12 \pm 1$ & $11 \pm 1$ & $5.25 \pm 0.03$ \\
\hline $1.9 \pm 0.2$ & $2.8 \pm 0.2$ & $1.6 \pm 0.2$ \\
$0.9 \pm 0.1$ & $1.7 \pm 0.2$ & $1.3 \pm 0.1$ \\
\hline $5.56 \pm 0.01$ & $3.3 \pm 0.2$ & $2.6 \pm 0.2$ \\
\hline
\end{tabular}

\begin{tabular}{ccc}
$2^{\text {nd }} \mathbf{H D}$ & Cornicabra \\
$11 \pm 1$ & $\mathbf{3}^{\text {rd }} \mathbf{H D}$ & $\mathbf{4}^{\text {th }} \mathbf{H D}$ \\
0 & $20 \pm 1$ & $18 \pm 1$ \\
$3.1 \pm 0.1$ & $13 \pm 1$ & $8.7 \pm 0.7$ \\
0 & 0 & 0 \\
0 & 0 & 0 \\
0 & 0 & 0 \\
$4.9 \pm 0.2$ & $0.84 \pm 0.01$ & $3.1 \pm 0.3$ \\
0 & $18.0 \pm 0.5$ & $10.4 \pm 0.9$ \\
0 & 0 & 0 \\
0 & $20.5 \pm 0.5$ & $9.7 \pm 0.7$ \\
$14 \pm 1$ & $20 \pm 1$ & $26 \pm 1$ \\
0 & 0 & 0 \\
$44 \pm 4$ & 0 & $11.8 \pm 0.4$ \\
0 & 0 & 0 \\
$2.5 \pm 0.2$ & $2.1 \pm 0.2$ & $2.4 \pm 0.3$ \\
$3.6 \pm 0.3$ & 0 & 0 \\
\hline & &
\end{tabular}

$\begin{array}{ccc}0.8 \pm 0.1 & 3.0 \pm 0.2 & 5.2 \pm 0.5 \\ 0 & 1.0 \pm 0.1 & 1.65 \pm 0.03 \\ 6.4 \pm 0.3 & 4.3 \pm 0.5 & 0.99 \pm 0.09 \\ 0.010 \pm 0.001 & 0.07 \pm 0.01 & 0.43 \pm 0.01\end{array}$

$0 \quad 2.6 \pm 0.3$

$\begin{array}{lll}0 & 0.90 \pm 0.03 & 1.9 \pm 0.1\end{array}$

$\begin{array}{ccc}12.9 \pm 0.7 & 1.7 \pm 0.1 & 1.4 \pm 0.1\end{array}$

$\begin{array}{lll}0 & 0 & 0.53 \pm 0.03\end{array}$

$\begin{array}{ccc}0.010 \pm 0.001 & 0.07 \pm 0.01 & 0.43 \pm 0.01 \\ 3.7 \pm 0.2 & 4.5 \pm 0.5 & 1.85 \pm 0.02\end{array}$

$\begin{array}{ccc}3.25 \pm 0.03 & 2.30 \pm 0.08 \quad 3.9 \pm 0.3\end{array}$

Higher concentration

\begin{tabular}{ccc}
$6.4 \pm 0.5$ & $5.4 \pm 0.5$ & $4.1 \pm 0.2$ \\
0 & 0 & 0 \\
$5.7 \pm 0.1$ & $3.9 \pm 0.2$ & $4.0 \pm 0.2$ \\
$17.9 \pm 0.7$ & $11.3 \pm 0.5$ & $6.6 \pm 0.4$ \\
\hline $3.4 \pm 0.2$ & $9.8 \pm 0.5$ & $14.3 \pm 0.4$
\end{tabular}

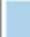

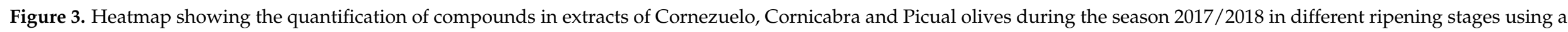
colour scale. Data are given as percentage \pm standard deviation $(n=3)$. 


\section{8/2019}

\section{№ Secoiridoids}

5 Oleoside/secologanoside

6 Oleoside-11-methylester

7 Oleuropein aglycone

9 Elenolic acid glucoside

10 Dimethyl-oleuropein glucoside

15 Dihydrooleuropein

16 Oleuropein glucoside

17 Oleuropein glucoside

$186^{\prime}-\beta$-Hexopyranosyloleoside

20 Elenolic acid derivative

21 Oleuropein

22 Comselogoside isomer

23 Oleuropein isomer

24 Comselogoside isomer

26 Ligstroside

27 Oleoside/secologanoside derivative

\section{Other compounds}

3 Hydroxytyrosol glucoside

11 Hydroxytyrosol glucoside derivative

12 Rutin

13 Verbascoside

14 Luteolin-O-hexoside

\begin{tabular}{|cccc}
\multicolumn{4}{c}{ Cornezuelo } \\
$\mathbf{1}^{\text {st }} \mathbf{H D}$ & $\mathbf{2}^{\text {nd }} \mathbf{H D}$ & $\mathbf{3}^{\text {rd }} \mathbf{H D}$ & $\mathbf{4}^{\text {th }} \mathbf{H D}$ \\
\hline $9 \pm 1$ & $11.46 \pm 0.09$ & $16.5 \pm 0.8$ & $26 \pm 2$ \\
$4.3 \pm 0.2$ & $6.6 \pm 0.6$ & $11.3 \pm 0.3$ & $15.3 \pm 0.6$ \\
$0.77 \pm 0.03$ & $0.72 \pm 0.03$ & $1.02 \pm 0.02$ & 0 \\
$5.6 \pm 0.7$ & $4.23 \pm 0.01$ & $11.1 \pm 0.8$ & $10.5 \pm 0.8$ \\
0 & 0 & 0 & 0 \\
$1.6 \pm 0.2$ & $1.3 \pm 0.2$ & $0.71 \pm 0.08$ & $0.55 \pm 0.05$ \\
$2.2 \pm 0.2$ & $1.94 \pm 0.09$ & $1.5 \pm 0.1$ & $0.92 \pm 0.04$ \\
$0.92 \pm 0.01$ & 0 & $1.9 \pm 0.1$ & $1.7 \pm 0.1$ \\
$11 \pm 1$ & $9.7 \pm 0.1$ & $5.2 \pm 0.3$ & $3.8 \pm 0.1$ \\
0 & 0 & 0 & $1.57 \pm 0.07$ \\
$21 \pm 2$ & $23 \pm 2$ & $21 \pm 1$ & $19 \pm 1$ \\
$22 \pm 2$ & $19.31 \pm 0.03$ & $11.3 \pm 0.2$ & $6.6 \pm 0.2$ \\
$12 \pm 1$ & $11.3 \pm 0.6$ & $5.7 \pm 0.2$ & $3.3 \pm 0.2$ \\
$1.9 \pm 0.2$ & $1.49 \pm 0.06$ & $0.82 \pm 0.02$ & $0.76 \pm 0.04$ \\
$2.8 \pm 0.3$ & $2.3 \pm 0.2$ & $3.1 \pm 0.3$ & $1.2 \pm 0.1$ \\
$3.2 \pm 0.3$ & $2.63 \pm 0.01$ & $2.7 \pm 0.3$ & $1.55 \pm 0.04$
\end{tabular}

\begin{tabular}{|c|c|c|c|}
\hline \multicolumn{4}{|c|}{ Cornicabra } \\
\hline $1^{\text {st }} H D$ & $2^{\text {nd }}$ HD & $3^{\text {rd }}$ HD & $4^{\text {th }} H D$ \\
\hline $9.0 \pm 0.8$ & $24 \pm 2$ & $23.4 \pm 0.8$ & $32 \pm 2$ \\
\hline $14 \pm 1$ & $17 \pm 1$ & $16 \pm 1$ & $15 \pm 1$ \\
\hline $0.64 \pm 0.01$ & $0.40 \pm 0.04$ & $0.42 \pm 0.02$ & 0 \\
\hline 0 & 0 & 0 & 0 \\
\hline $4.1 \pm 0.4$ & 0 & 0 & 0 \\
\hline $0.9 \pm 0.1$ & $0.65 \pm 0.04$ & $0.50 \pm 0.06$ & $0.59 \pm 0.06$ \\
\hline $1.4 \pm 0.1$ & $3.29 \pm 0.09$ & $1.7 \pm 0.2$ & $1.3 \pm 0.1$ \\
\hline 0 & 0 & 0 & 0 \\
\hline $3.7 \pm 0.1$ & $2.69 \pm 0.09$ & $3.6 \pm 0.3$ & $3.0 \pm 0.2$ \\
\hline 0 & 0 & $1.50 \pm 0.08$ & $11 \pm 1$ \\
\hline $27 \pm 2$ & $27 \pm 2$ & $19 \pm 1$ & $10.6 \pm 0.8$ \\
\hline $9.8 \pm 0.8$ & $6.6 \pm 0.3$ & $7.5 \pm 0.6$ & $55 \pm 0.2$ \\
\hline $15 \pm 1$ & $7.8 \pm 0.3$ & $7.5 \pm 0.8$ & $2.3 \pm 0.2$ \\
\hline 0 & 0 & 0 & $0.68 \pm 0.04$ \\
\hline $7.9 \pm 0.7$ & $3.3 \pm 0.3$ & $4.5 \pm 0.3$ & $1.74 \pm 0.09$ \\
\hline $2.6 \pm 0.2$ & 0 & 0 & 0 \\
\hline
\end{tabular}

\begin{tabular}{|cccc|}
\multicolumn{4}{c}{ Picual } \\
$\mathbf{1}^{\text {st }} \mathbf{H D}$ & $\mathbf{2}^{\text {nd }} \mathbf{H D}$ & $\mathbf{3}^{\text {rd }} \mathbf{H D}$ & $\mathbf{4}^{\text {th }} \mathbf{H D}$ \\
\hline $10 \pm 1$ & $9.4 \pm 0.1$ & $11 \pm 1$ & $16 \pm 2$ \\
$7.4 \pm 0.8$ & $6.9 \pm 0.5$ & $8.1 \pm 0.6$ & $8.7 \pm 0.6$ \\
\hline $0.9 \pm 0.1$ & $0.90 \pm 0.03$ & $0.90 \pm 0.07$ & $0.63 \pm 0.01$
\end{tabular}

$\begin{array}{llll}0.9 \pm 0.1 & 0.90 \pm 0.03 & 0.90 \pm 0.07 & 0.63 \pm 0.01\end{array}$

$\begin{array}{cccc}2.63 \pm 0.05 & 0 & 0 & 0\end{array}$

$\begin{array}{cccc}0 & 0 & 0 & 0 \\ .05 \pm 0.08 & 1.1 \pm 0.1 & 0.67 \pm 0.07 & 0.86 \pm 0.08\end{array}$

$\begin{array}{llll}1.3 \pm 0.1 & 1.6 \pm 0.2 & 1.1 \pm 0.1 & 1.20 \pm 0.03\end{array}$

$\begin{array}{cccc}0 & 0 & 0.60 \pm 0.06 & 0\end{array}$

$\begin{array}{cccc}8.14 \pm 0.05 & 8.2 \pm 0.8 & 6.2 \pm 0.2 & 6.2 \pm 0.3\end{array}$

$\begin{array}{cccc}0 & 0 & 1.8 \pm 0.1 & 0\end{array}$

$\begin{array}{ccccc}27 \pm 1 & 22 \pm 1 & 29 \pm 1 & 24 \pm 1 \\ 10.8 \pm 0.2 & 11.8 \pm 0.8 & 8.0 \pm 0.3 & 7.0 \pm 0.5\end{array}$

\begin{tabular}{c|c|c|c}
$13 \pm 1$ & $23 \pm 2$ & $13 \pm 1$ & $17.7 \pm 0.5$
\end{tabular}

$\begin{array}{cccc}0.66 \pm 0.08 & 0 & 0 & 0\end{array}$

$\begin{array}{llll}4.3 \pm 0.5 & 2.8 \pm 0.3 & 3.5 \pm 0.3 & 3.0 \pm 0.3\end{array}$

$2.31 \pm 0.02 \quad 2.1 \pm 0.2 \quad 1.63 \pm 0.06 \quad 1.31 \pm 0.01$

\section{\begin{tabular}{ccc|c|c}
$0.86 \pm 0.04$ & $3.9 \pm 0.1$ & $9.2 \pm 0.8$ & $11.9 \pm 0.8$ \\
\hline 0 & $0.87 \pm 0.09$ & $1.0 \pm 0.1$ & $0.96 \pm 0.02$
\end{tabular}}

$\begin{array}{cccc}5.1 \pm 0.5 & 3.6 \pm 0.3 & 3.2 \pm 0.3 & 4.8 \pm 0.3 \\ 0 & 0 & 0 & 0 \\ 2.0 \pm 0.2 & 2.4 \pm 0.2 & 4.8 \pm 0.4 & 2.57 \pm 0.03 \\ 2.4 \pm 0.2 & 1.5 \pm 0.1 & 1.5 \pm 0.1 & 2.8 \pm 0.1 \\ 0.74 \pm 0.08 & 2.8 \pm 0.3 & 5.6 \pm 0.6 & 3.9 \pm 0.3\end{array}$

wer concentration

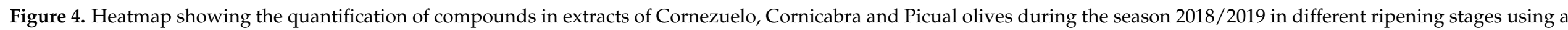
colour scale. Data are given as percentage \pm standard deviation $(n=3)$. 
For verbascoside, the variety with the lowest concentration was Cornicabra (1.54 and $3.08 \mathrm{mg} / 100 \mathrm{~g}$ FW in seasons 2017/2018 and 2018/2019, respectively); these values are very similar to that previously reported in literature in Cornicabra olives (3.5 mg/100 g FW) [10]. The highest concentration of verbascoside was observed in the Picual variety $(26 \mathrm{mg} / 100 \mathrm{~g}$ FW), in agreement with a previous study that also reported that the Picual variety had a high concentration of this compound (124 mg/100 $\mathrm{g} \mathrm{FW)} \mathrm{[13].} \mathrm{In} \mathrm{other} \mathrm{varieties,} \mathrm{concentra-}$ tions of $36 \mathrm{mg} / 100 \mathrm{~g}$ FW in the Spanish variety Royal [33] and $111 \mathrm{mg} / 100 \mathrm{~g}$ FW in the Turkish variety Sariulak [2] were reported.

Comparing Cornezuelo with Cornicabra and Picual, it could be observed that the TIPC was the highest in Cornezuelo (Tables 2-4; Figure 5) at the last HD, which is the usual harvesting date. This difference was mainly due to compounds 5 and $\mathbf{6}$ (oleoside/secologanoside and oleoside-11-methylester), which were much more abundant in Cornezuelo. Regarding oleuropein, the highest values were observed in Picual (13-191 mg/100 g FW) and Cornezuelo (24-160 mg/100g FW), whereas Cornicabra presented the lowest values not only of oleuropein (9-80 mg/100 $\mathrm{g} \mathrm{FW)} \mathrm{but} \mathrm{also} \mathrm{of} \mathrm{rutin} \mathrm{and}$ verbascoside.

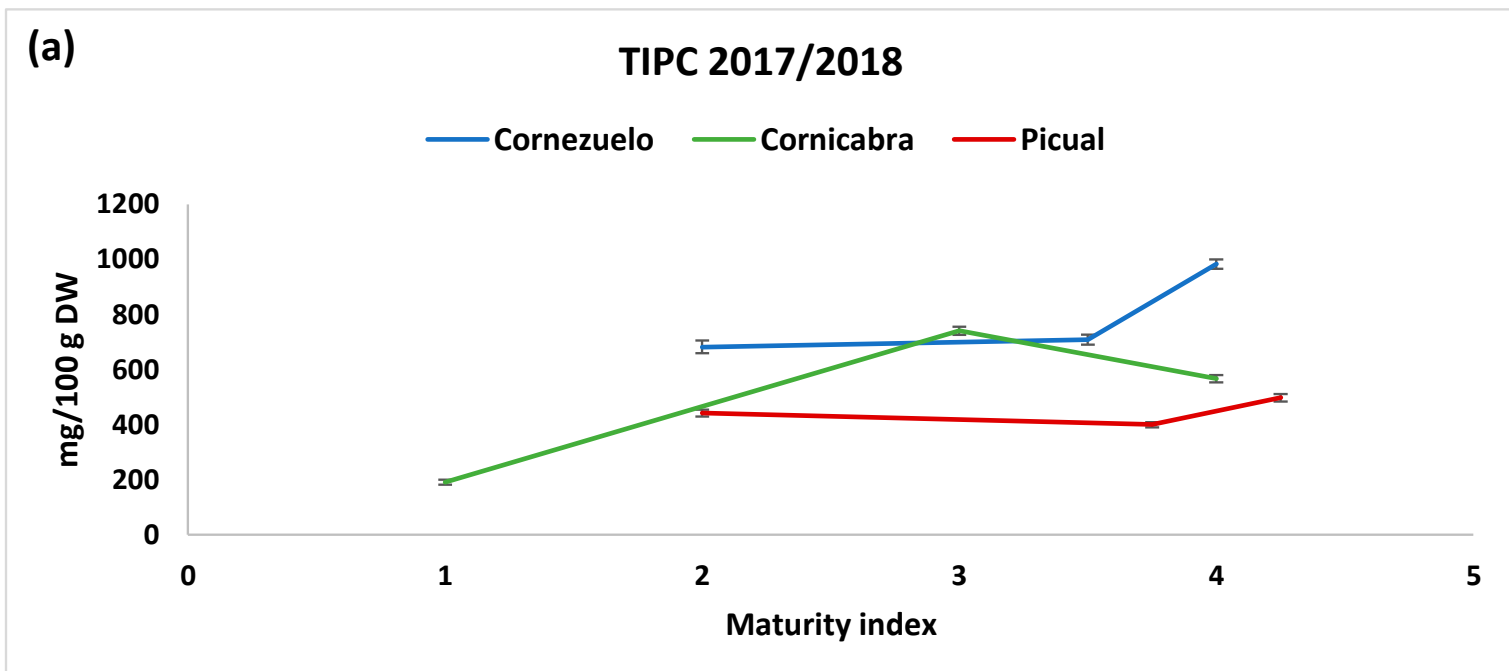

(b)

TIPC 2018/2019

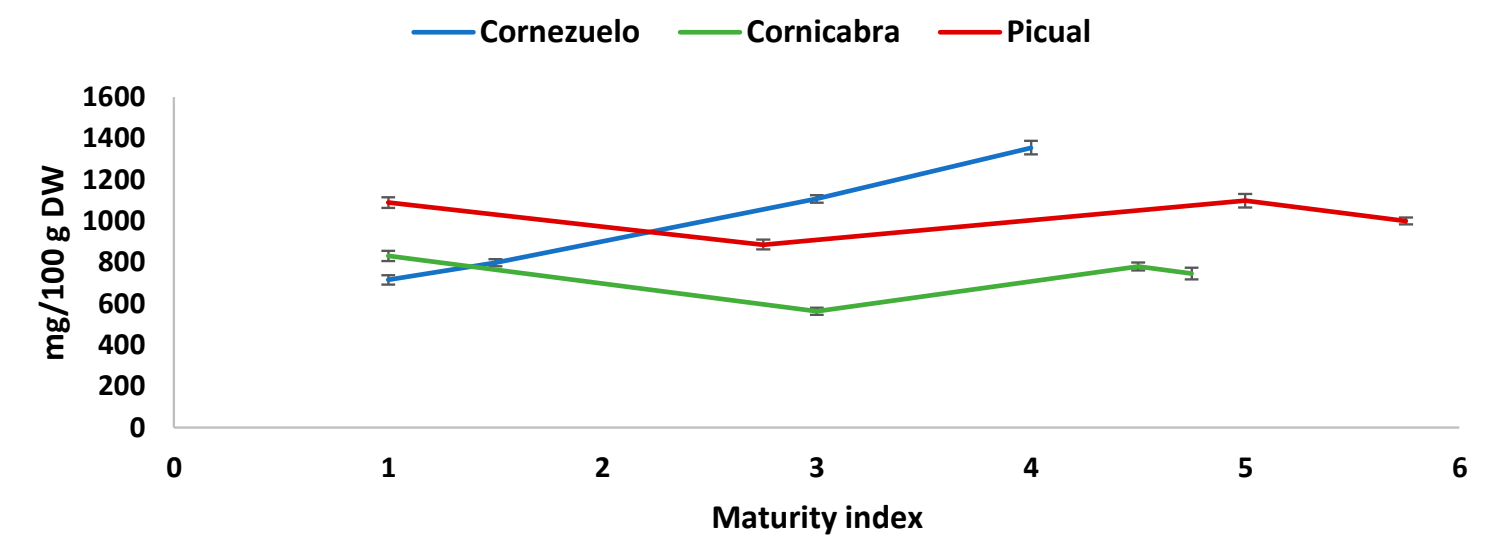

Figure 5. TIPC of the three varieties of olive fruits in the different collection months during seasons 2017/2018 (a) and 2018/2019 (b). Values (mg/100 g dry weight) are mean \pm SD of three parallel measurements. 


\subsection{Influence of Ripening on Phenolic Content}

Regarding the influence of the HD (Figure 5), there was a general trend indicating that TIPC increased during the maturation process in most cases, observing the highest phenolic content in the last two HDs (corresponding approximately to maturity indexes higher than 3.5), which are the usual collecting dates for these varieties in the location areas under study. This trend was observed in both harvesting seasons. Some authors have reported decreases in total phenolics [11] or individual compounds such as oleuropein [38] along with the maturation process. Different behaviours have also been reported depending on the variety [39]. However, phenolic concentration usually increases during the maturation process until it reaches a maximum (during spotted and purple pigmentation), and then decreases [15]. In our study, we observed this trend as the ripening increased, although the decrease was not observed because the maturation indexes were not higher than five (black olive, with purple colour in less than the half of the pulp), when phenolics should decrease. Only for the last HD in Picual was the maturation index higher than 5, and there was a slight decrease in phenolic content (Table 4).

In the two first HDs there were no considerable variations between the values of TIPC for the three olive varieties. However, as fruit ripening progressed, olives from Cornezuelo and Cornicabra varieties showed increased amounts of secoiridoids and TIPC (Figure 5), whereas those from Picual did not change significantly. Among varieties, Cornezuelo and Picual presented higher TIPC values $(840 \mathrm{mg} / 100 \mathrm{~g}$ and $670 \mathrm{mg} / 100 \mathrm{~g}$, respectively) than Cornicabra variety $(530 \mathrm{mg} / 100 \mathrm{~g})$.

In a previous work in Memecik olive variety, the concentration of oleuropein increased during fruit ripening, from $459 \mathrm{mg} / 100 \mathrm{~g}$ to $994 \mathrm{mg} / 100 \mathrm{~g}$ [40], which is the same behaviour observed in the varieties we studied during the maturation process. This trend was also previously registered in Morisca variety, with values ranging from $195 \mathrm{mg} / 100 \mathrm{~g}$ FW to $264 \mathrm{mg} / 100 \mathrm{~g}$ FW [10].

In the Cornezuelo variety there was an increase in the concentration of the main secoiridoids as the olive matured. During season 2018/2019, oleoside/secologanoside, oleoside-11-methylester and oleuropein values were $25,12.3$, and $61 \mathrm{mg} / 100 \mathrm{~g}$, respectively, in 1st HD, and they reached values of 220, 128 and $160 \mathrm{mg} / 100 \mathrm{~g}$, respectively, in the 4th HD. This trend was also observed in the total content of secoiridoids. Similarly, the TIPC in this variety increased from $286 \mathrm{mg} / 100 \mathrm{~g}$ to $840 \mathrm{mg} / 100 \mathrm{~g}$ during olive ripening.

In Cornicabra variety, an increase in the concentrations of oleoside/secologanoside ( $24 \mathrm{mg} / 100 \mathrm{~g}$ to $170 \mathrm{mg} / 100 \mathrm{~g}$ ) and oleoside-11-methylester ( $38 \mathrm{mg} / 100 \mathrm{~g}$ to $81 \mathrm{mg} / 100 \mathrm{~g}$ ) was also observed during fruit ripening. Regarding the total concentration of secoiridoids and TIPC, they decreased in the 2nd HD but increased for later maturation stages.

In Picual variety, there was also an increase in the concentration of oleoside/ secologanoside ( $38 \mathrm{mg} / 100 \mathrm{~g}$ to $100 \mathrm{mg} / 100 \mathrm{~g})$ and oleoside-11-methylester $(29 \mathrm{mg} / 100 \mathrm{~g}$ to $56 \mathrm{mg} / 100 \mathrm{~g})$. Oleuropein reached the highest value in $3 \mathrm{rd} \mathrm{HD}(191 \mathrm{mg} / 100 \mathrm{~g})$. The behaviour of the total content of secoiridoids and the TIPC in Picual olive fruits were similar: in the two first HDs they remained constant (350-352 mg/100 $\mathrm{g}$ for the total content of secoiridoids and 390-392 mg/100 $\mathrm{g}$ for TIPC) and then increased with fruit maturation up to $550-570 \mathrm{mg} / 100 \mathrm{~g}$ and $640-670 \mathrm{mg} / 100 \mathrm{~g}$, respectively.

To sum up, phenolic content increased during the maturation process, similarly to the trend reported in previous works, up to a maturation index of 5, at which point phenolic values are reported to decrease (an effect observed in the last HD of Picual variety). The initial hypothesis of the three olive varieties following a similar trend in phenolic concentration was confirmed, although slight variations were observed depending on the maturity index. In addition, the highest concentration of TIPC was observed in the usual olive collection dates for each olive variety (third and fourth HD).

\subsection{Mineral Components}

Although the main objective of this work was to study the influence of olive fruits maturation on the phenolic composition, we also studied the mineral components by ICP- 
MS. Table 5 shows the ranges of concentration levels of minerals in fruits on the analysed cultivars at different harvest dates and crops seasons evaluated. The average concentration levels obtained in each olive variety are given in Supplementary Material in Tables S6-S8. The differences observed in the different HDs and harvesting seasons are due to different humidity percentages, climatologic conditions and geographical locations. Taking into account that there were four HDs in season 2018/2019 and that phenolic concentrations were higher, the following discussion focuses on this season.

Table 5. Concentrations of mineral in foods of the analysed olive cultivars at two different harvest seasons.

\begin{tabular}{ccccccc}
\hline & \multicolumn{2}{c}{ CORNEZUELO } & \multicolumn{2}{c}{ CORNICABRA } & \multicolumn{2}{c}{ PICUAL } \\
Element & $\mathbf{2 0 1 7 / 2 0 1 8}$ & $\mathbf{2 0 1 8 / 2 0 1 9}$ & $\mathbf{2 0 1 7 / 2 0 1 8}$ & $\mathbf{2 0 1 8 / 2 0 1 9}$ & $\mathbf{2 0 1 7 / 2 0 1 8}$ & $\mathbf{2 0 1 8 / 2 0 1 9}$ \\
\hline $\mathrm{As}$ & $0.231-0.260$ & $0.100-0.108$ & $0.224-0.255$ & $0.095-0.103$ & $0.23-0.26$ & $0.091-0.100$ \\
$\mathrm{Ba}$ & $0.24-0.27$ & - & $0.874-0.950$ & $0.56-0.83$ & $0.35-0.54$ & $0.099-0.122$ \\
$\mathrm{Ca}$ & $370-620$ & $260-690$ & $590-980$ & $440-810$ & $340-700$ & $187-510$ \\
$\mathrm{Cd}$ & $0.145-0.160$ & $0.009-0.010$ & $0.138-0.157$ & $0.080-0.083$ & $0.15-0.16$ & $0.079-0.084$ \\
$\mathrm{Cu}$ & $1.4-2.0$ & $1.67-3.9$ & $1.47-3.30$ & $4.1-6.7$ & $2.38-4.35$ & $3.5-10.0$ \\
$\mathrm{Fe}$ & 10.0 & Detected * & Detected * & $2.5-4.9$ & Detected * & $1.84-2.5$ \\
$\mathrm{~K}$ & $4600-5700$ & $5400-7600$ & $7000-11,400$ & $7200-10,800$ & $5300-10,100$ & $5700-7000$ \\
$\mathrm{Mg}$ & $130-180$ & $150-210$ & $126-209$ & $160-202$ & $109-257$ & $119-152$ \\
$\mathrm{Mn}$ & $1.30-1.86$ & $1.4-1.8$ & $1.42-2.30$ & $1.9-3.0$ & $1.31-2.00$ & $1.16-1.40$ \\
$\mathrm{Mo}$ & $0.122-0.139$ & - & $0.131-0.168$ & - & $0.13-0.15$ & - \\
$\mathrm{Na}$ & - & 5.1 & - & $3.4-6.3$ & - & $2.90-4.05$ \\
$\mathrm{Ni}$ & Detected * & $0.046-0.058$ & Detected * & $0.236-0.510$ & Detected * & $0.062-0.180$ \\
$\mathrm{P}$ & $330-430$ & $410-600$ & $200-380$ & $320-700$ & $260-458$ & $380-830$ \\
$\mathrm{Sb}$ & $0.075-0.088$ & $0.071-0.089$ & $0.073-0.084$ & - & $0.080-0.083$ & - \\
$\mathrm{Sn}$ & Detected * & - & Detected * & - & Detected * & - \\
$\mathrm{Ti}$ & - & - & - & $0.072-0.075$ & - & 0.13 \\
$\mathrm{Zn}$ & $2.8-3.7$ & $2.48-3.20$ & $2.6-2.8$ & $3.22-5.54$ & $2.53-4.30$ & $1.70-2.53$ \\
\hline
\end{tabular}

Data are expressed as ranges of concentrations ( $\mu \mathrm{g} \mathrm{g}^{-1}$ fresh weight) of three (2017/2018 season) or four (2018/2019 season) harvest times.

* Concentrations between detection and quantitation limits.

Potassium was dominant in all olive varieties; the highest concentration was found in cv. Cornicabra (7200-10,800 $\mathrm{g} \mathrm{g} \mathrm{g}^{-1}$ ). In Cornezuelo and Picual varieties, values of $5400-7600 \mu^{-1} \mathrm{~g}^{-1}$ and $5700-7000 \mu \mathrm{g} \mathrm{g}^{-1}$, respectively, were obtained. In previous studies, the concentration of $\mathrm{K}$ was very different depending on the olive variety: $55,000 \mathrm{\mu g} \mathrm{g}^{-1}$ in Leccino variety [41], and $216 \mu \mathrm{g} \mathrm{g}^{-1}$ in Arauco and Arbequina varieties [42].

Calcium was also present at high concentrations (510-810 $\mu \mathrm{g} \mathrm{g}^{-1}$ ); the highest one was observed in cv. Cornicabra. Overall, these concentrations are similar to that previously found in cv. Leccino [41] and higher than those in both Arbequina and Arauco cultivars [42].

The range of copper concentrations were 1.67-3.9 $\mu \mathrm{g} \mathrm{g}^{-1}, 4.1-6.7 \mu \mathrm{g} \mathrm{g}^{-1}$ and 3.5-10 $\mathrm{\mu g} \mathrm{g}^{-1}$ for Cornezuelo, Cornicabra and Picual varieties, respectively. These values were higher than those reported in a previous work on Arbequina, Arauco and Hojiblanca: $0.42-2.4 \mu \mathrm{g} \mathrm{g}^{-1}[42,43]$. This difference is usually due to the use of copper-based fungicides to control diseases in olive trees, and the specific dose and application timing of these fungicides directly affect copper concentration in olives. Nevertheless, a Fe concentration of $2.4 \mu \mathrm{g} \mathrm{g}^{-1}$ was found in those varieties, similar to the obtained values in the present study $\left(1.84-4.9 \mu \mathrm{g} \mathrm{g}^{-1}\right)$.

Lower concentrations of manganese were observed in Cornezuelo, Cornicabra and Picual varieties (1.4-1.8 $\mu \mathrm{g} \mathrm{g}^{-1}, 1.9-3.0 \mu \mathrm{g} \mathrm{g}^{-1}$ and 1.16-1.40 $\mu \mathrm{g} \mathrm{g}^{-1}$, respectively) compared to those reported in bibliography in Leccino olives $\left(7.8 \mu \mathrm{g} \mathrm{g}^{-1}\right)$ [41]. On the other hand, the maximum phosphorus concentrations for the varieties under studied were $600 \mathrm{\mu g} \mathrm{g}^{-1}$, $700 \mu \mathrm{g} \mathrm{g}^{-1}$ and $830 \mu \mathrm{g} \mathrm{g}^{-1}$, respectively. These maximum concentrations were reached in the $4^{\text {th }} \mathrm{HD}$ and were higher than those of Arbequina and Arauco varieties $\left(55 \mu \mathrm{g} \mathrm{g}^{-1}\right)$ [42].

Arsenic concentration for each of the varieties remained statistically constant throughout the study $\left(0.100-0.108 \mu \mathrm{g} \mathrm{g}^{-1}, 0.095-0.103 \mu \mathrm{g} \mathrm{g}{ }^{-1}\right.$ and $0.091-0.100 \mu \mathrm{g} \mathrm{g}^{-1}$ in Cornezuelo, Cornicabra and Picual respectively). Similarly, cadmium values remained constant during 
the ripening of the olives $\left(0.009-0.010 \mu \mathrm{g} \mathrm{g}^{-1}, 0.080-0.083 \mu \mathrm{g} \mathrm{g}^{-1}\right.$ and $0.079-0.084 \mu \mathrm{g} \mathrm{g}^{-1}$, respectively). Both toxic elements were thus present at low levels in all samples. The concentrations of $\mathrm{Ag}, \mathrm{Co}, \mathrm{Cr}, \mathrm{Mo}, \mathrm{Pb}, \mathrm{Sn}$, and $\mathrm{V}$ were below method detection limits in all cases.

\section{Conclusions}

In this work, we studied the effect of the ripening process on the phenolic composition and mineral content of three olive varieties: Cornezuelo, Cornicabra and Picual. This study was performed during two consecutive seasons. In all cases, most of the compounds were secoiridoids, mainly oleuropein, as expected. Cornezuelo olives had the highest total phenolic content. Phenolic concentration increased during the maturation process, up to a maturation index of approximately 5 . The highest phenolic levels were observed in the third and fourth HD, which are the usual olive collection dates. The hypothesis of a similar trend in the levels of phenolics in the different olive variety was confirmed, although some differences were observed, mainly in Picual olives. However, no clear trend was observed regarding mineral composition. The sharpest increase in phenolics concentration was observed in Cornezuelo olives, which is in agreement with its latest collection date compared to the other varieties.

Supplementary Materials: The following are available online at https:/ / www.mdpi.com/2304-815 8/10/2/380/s1. Chromatographic conditions; ICP-MS characteristics; Table S1: ICP-MS operating conditions; Table S2: Analysis of the cranberry certified reference material (NIST-3281); Table S3: Method detection limits for the analysed elements in ICP-MS; Table S4: Digestion procedure conditions; Table S5: Humidity percentages of all the olive samples analysed; Tables S6-S8: Average concentration levels of minerals and trace elements in the analysed Cornezuelo, Cornicabra and Picual olives in different months of two seasons; Figure S1: Recovery yields with the olives of the sample "Cornicabra 1st HD".

Author Contributions: M.d.P.F.-P.: Methodology, investigation, formal analysis, data curation, writing-original draft. E.J.L.-M.: Methodology, supervision, conceptualization, data curation, writing-review \& editing. A.R.-M.: Methodology, supervision, conceptualization, writing-review \& editing. All authors have read and agreed to the published version of the manuscript.

Funding: This research received no external funding.

Institutional Review Board Statement: Not applicable.

Informed Consent Statement: Not applicable.

Data Availability Statement: Data available on request.

Acknowledgments: Technical and human support provided by CICT of Universidad de Jaén (UJA, MINECO, Junta de Andalucía, FEDER) is gratefully acknowledged.

Conflicts of Interest: The authors declare no conflict of interest.

$\begin{array}{ll}\text { Abbreviations } \\ \text { 1st } & \text { October } \\ \text { 2nd } & \text { November } \\ \text { 3rd } & \text { December } \\ \text { 4th } & \text { January } \\ \text { DE } & \text { Dried extract } \\ \text { FW } & \text { Fresh weight } \\ \text { HD } & \text { Harvest date } \\ m / z & \text { Mass to charge ratio } \\ \text { SD } & \text { Standard deviation } \\ \text { TIPC } & \text { Total individual phenolic content } \\ t_{\mathrm{R}} & \text { Retention time }\end{array}$




\section{References}

1. Loumou, A.; Giourga, C. Olive groves: The life and identity of the Mediterranean. Agric. Hum. Values 2003, 20, 87-95. [CrossRef]

2. Arslan, D.; Özcan, M.M. Phenolic profile and antioxidant activity of olive fruits of the Turkish variety "Sarıulak" from different locations. Grasas Aceites 2011, 62, 453-461. [CrossRef]

3. Hbaieb, R.H.; Kotti, F.; García-Rodríguez, R.; Gargouri, M.; Sanz, C.; Pérez, A.G. Monitoring endogenous enzymes during olive fruit ripening and storage: Correlation with virgin olive oil phenolic profiles. Food Chem. 2015, 174, 240-247. [CrossRef]

4. Brahmi, F.; Mechri, B.; Dhibi, M.; Hammami, M. Variations in phenolic compounds and antiradical scavenging activity of Olea europaea leaves and fruits extracts collected in two different seasons. Ind. Crops Prod. 2013, 49, 256-264. [CrossRef]

5. Kumar, V.; Irfan, M.; Ghosh, S.; Chakraborty, N.; Chakraborty, S.; Datta, A. Fruit ripening mutants reveal cell metabolism and redox state during ripening. Protoplasma 2016, 253, 581-594. [CrossRef] [PubMed]

6. Silva, S.; Gomes, L.; Leitão, F.; Coelho, A.V.; Boas, L.V. Phenolic compounds and antioxidant activity of Olea europaea L. fruits and leaves. Food Sci. Technol. Int. 2006, 12, 385-396. [CrossRef]

7. Fregapane, G.; Salvador, M.D. Production of superior quality extra virgin olive oil modulating the content and profile of its minor components. Food Res. Int. 2013, 54, 1907-1914. [CrossRef]

8. Bouaziz, M.; Chamkha, M.; Sayadi, S. Comparative study on phenolic content and antioxidant activity during maturation of the olive cultivar Chemlali from Tunisia. J. Agric. Food Chem. 2004, 52, 5476-5481. [CrossRef]

9. Moure, A.; Cruz, J.M.; Franco, D.; Domínguez, J.M.; Sineiro, J.; Domínguez, H.; Núñez, M.J.; Parajó, J.C. Natural antioxidants from residual sources. Food Chem. 2001, 72, 145-171. [CrossRef]

10. Gómez-Rico, A.; Fregapane, G.; Salvador, M.D. Effect of cultivar and ripening on minor components in Spanish olive fruits and their corresponding virgin olive oils. Food Res. Int. 2008, 41, 433-440. [CrossRef]

11. Gouvinhas, I.; Domínguez-Perles, R.; Gironés-Vilaplana, A.; Carvalho, T.; Machado, N.; Barros, A. Kinetics of the polyphenolic content and radical scavenging capacity in olives through on-tree ripening. J. Chem. 2017, 2017, 1-11. [CrossRef]

12. Ortega-Garcia, F.; Blanco, S.; Peinado, M.A.; Peragon, J. Polyphenol oxidase and its relationship with oleuropein concentration in fruits and leaves of olive (Olea europaea) cv. "Picual" trees during fruit ripening. Tree Physiol. 2008, 28, 45-54. [CrossRef] [PubMed]

13. Romero, C.; Medina, E.; Mateo, M.A.; Brenes, M. Quantification of bioactive compounds in Picual and Arbequina olive leaves and fruit. J. Sci. Food Agric. 2017, 97, 1725-1732. [CrossRef] [PubMed]

14. Bajoub, A.; Medina-Rodríguez, S.; Olmo-García, L.; Ajal, E.A.; Monasterio, R.P.; Hanine, H.; Fernández-Gutiérrez, A.; CarrascoPancorbo, A. In-depth two-year study of phenolic profile variability among olive oils from autochthonous and mediterranean varieties in Morocco, as revealed by a LC-MS chemometric profiling approach. Int. J. Mol. Sci. 2017, 18, 52. [CrossRef]

15. Salvador, M.D.; Aranda, F.; Fregapane, G. Influence of fruit ripening on "Cornicabra" virgin olive oil quality. A study of four successive crop seasons. Food Chem. 2001, 73, 45-53. [CrossRef]

16. Casas, J.S.; De Miguel Gordillo, C.; Bueno, E.O.; Expósito, J.M.; González, L.G.; Cano, M.M.; Cano, M.M. Sensory quality of virgin olive oils coming from olive varieties produced in Extremadura (Spain). Grasas Aceites 2006, 57, 313-318. [CrossRef]

17. Casas, J.S.; De Miguel Gordillo, C.; Bueno, E.O.; Expósito, J.M.; Mendoza, M.F.; Hierro, T.A.; González, L.G.; Cano, M.M. Characteristics of virgin olive oils from the olive zone of Extremadura (Spain), and an approximation to their varietal origin. J. Am. Oil Chem. Soc. 2009, 86, 933-940. [CrossRef]

18. Fernández-Poyatos, M.P.; Ruiz-Medina, A.; Llorent-Martínez, E.J. Phytochemical profile, mineral content, and antioxidant activity of Olea europaea L. cv. Cornezuelo table olives. Influence of in vitro simulated gastrointestinal digestion. Food Chem. 2019, 297, 124933. [CrossRef]

19. Abenoza, M.; Lasa Dolhagaray, J.M.; Benito, M.; Oria, R.; Sánchez-Gimeno, A.C. The evolution of Arbequina olive oil quality during ripening in a commercial super-high density orchard in north-east Spain. Riv. Ital. Delle Sostanze Grasse 2015, $92,83-92$. [CrossRef]

20. Talhaoui, N.; Gómez-Caravaca, A.M.; León, L.; De La Rosa, R.; Fernández-Gutiérrez, A.; Segura-Carretero, A. Pattern of variation of fruit traits and phenol content in olive fruits from six different cultivars. J. Agric. Food Chem. 2015, 63, 10466-10476. [CrossRef]

21. Malapert, A.; Reboul, E.; Loonis, M.; Dangles, O.; Tomao, V. Direct and rapid profiling of biophenols in olive pomace by UHPLC-DAD-MS. Food Anal. Methods 2018, 11, 1001-1010. [CrossRef]

22. Jiménez-López, J.; Ruiz-Medina, A.; Ortega-Barrales, P.; Llorent-Martínez, E.J. Rosa rubiginosa and Fraxinus oxycarpa herbal teas: Characterization of phytochemical profiles by liquid chromatography-mass spectrometry, and evaluation of the antioxidant activity. New J. Chem. 2017, 41, 7681-7688. [CrossRef]

23. Llorent-Martínez, E.J.; Gouveia, S.; Castilho, P.C. Analysis of phenolic compounds in leaves from endemic trees from Madeira Island. A contribution to the chemotaxonomy of Laurisilva forest species. Ind. Crops Prod. 2015, 64, 135-151. [CrossRef]

24. Rigane, G.; Salem, R.B.; Sayadi, S.; Bouaziz, M. Phenolic composition, isolation, and structure of a new deoxyloganic acid derivative from Dhokar and Gemri-Dhokar olive cultivars. J. Food Sci. 2011, 76, C965-C973. [CrossRef]

25. Savarese, M.; De Marco, E.; Sacchi, R. Characterization of phenolic extracts from olives (Olea europaea cv. Pisciottana) by electrospray ionization mass spectrometry. Food Chem. 2007, 105, 761-770. [CrossRef]

26. García-Villalba, R.; Larrosa, M.; Possemiers, S.; Tomás-Barberán, F.A.; Espín, J.C. Bioavailability of phenolics from an oleuropeinrich olive (Olea europaea) leaf extract and its acute effect on plasma antioxidant status: Comparison between pre- and postmenopausal women. Eur. J. Nutr. 2014, 53, 1015-1027. [CrossRef] 
27. Kanakis, P.; Termentzi, A.; Michel, T.; Gikas, E.; Halabalaki, M.; Skaltsounis, A.-L. From olive drupes to olive oil. An HPLCorbitrap-based qualitative and quantitative exploration of olive key metabolites. Planta Med. 2013, 79, 1576-1587. [CrossRef]

28. Fu, S.; Arráez-Roman, D.; Segura-Carretero, A.; Menéndez, J.A.; Menéndez-Gutiérrez, M.P.; Micol, V.; Fernández-Gutiérrez, A. Qualitative screening of phenolic compounds in olive leaf extracts by hyphenated liquid chromatography and preliminary evaluation of cytotoxic activity against human breast cancer cells. Anal. Bioanal. Chem. 2010, 397, 643-654. [CrossRef]

29. Jerman, T.; Trebše, P.; Vodopivec, B.M. Ultrasound-assisted solid liquid extraction (USLE) of olive fruit (Olea europaea) phenolic compounds. Food Chem. 2010, 123, 175-182. [CrossRef]

30. Llorent-Martínez, E.J.; Ortega-Barrales, P.; Zengin, G.; Mocan, A.; Simirgiotis, M.J.; Ceylan, R.; Uysal, S.; Aktumsek, A. Evaluation of antioxidant potential, enzyme inhibition activity and phenolic profile of Lathyrus cicera and Lathyrus digitatus: Potential sources of bioactive compounds for the food industry. Food Chem. Toxicol. 2017, 107, 609-619. [CrossRef]

31. Ren, L.; Xue, X.; Zhang, F.; Wang, Y.; Liu, Y.; Li, C.; Liang, X. Studies of iridoid glycosides using liquid chromatography/electrospray ionization tandem mass spectrometry. Rapid Commun. Mass Spectrom. 2007, 21, 3039-3050. [CrossRef] [PubMed]

32. Llorent-Martínez, E.J.; Spínola, V.; Castilho, P.C. Phenolic profiles of Lauraceae plant species endemic to Laurisilva forest: A chemotaxonomic survey. Ind. Crops Prod. 2017, 107, 1-12. [CrossRef]

33. Fernández-Poyatos, M.D.P.; Ruiz-Medina, A.; Llorent-Martínez, E.J. Phytochemical profile and mineral content of Royal variety olive fruits. Influence of the ripening stage. J. Food Compos. Anal. 2021, 95, 103671. [CrossRef]

34. Ferro, M.D.; Lopes, E.; Afonso, M.; Peixe, A.; Rodrigues, F.M.; Duarte, M.F. Phenolic profile characterization of "Galega Vulgar" and "Cobrançosa" Portuguese olive cultivars along the ripening stages. Appl. Sci. 2020, 10, 3930. [CrossRef]

35. Jemai, H.; Bouaziz, M.; Sayadi, S. Phenolic composition, sugar contents and antioxidant activity of Tunisian sweet olive cultivar with regard to fruit ripening. J. Agric. Food Chem. 2009, 57, 2961-2968. [CrossRef]

36. Othman, N.B.; Roblain, D.; Chammen, N.; Thonart, P.; Hamdi, M. Antioxidant phenolic compounds loss during the fermentation of Chétoui olives. Food Chem. 2009, 116, 662-669. [CrossRef]

37. Dağdelen, A.; Tümen, G.; Özcan, M.M.; Dündar, E. Phenolics profiles of olive fruits (Olea europaea L.) and oils from Ayvalik, Domat and Gemlik varieties at different ripening stages. Food Chem. 2013, 136, 41-45. [CrossRef] [PubMed]

38. Ortega-García, F.; Peragón, J. Phenylalanine ammonia-lyase, polyphenol oxidase, and phenol concentration in fruits of Olea europaea L. cv. Picual, Verdial, Arbequina, and Frantoio during ripening. J. Agric. Food Chem. 2009, 57, 10331-10340. [CrossRef] [PubMed]

39. Ryan, D.; Robards, J.; Lavee, S. Changes in phenolic content of olive during maturation. Int. J. Food Sci. Tech. 1999, 34, 265-274. [CrossRef]

40. Yorulmaz, A.; Erinc, H.; Tekin, A. Changes in olive and olive oil characteristics during maturation. J. Am. Oil Chem. Soc. 2013, 90, 647-658. [CrossRef]

41. D'Amato, R.; Petrelli, M.; Proietti, P.; Onofri, A.; Regni, L.; Perugini, D.; Businelli, D. Determination of changes in the concentration and distribution of elements within olive drupes (cv. Leccino) from Se biofortified plants, using laser ablation inductively coupled plasma mass spectrometry. J. Sci. Food Agric. 2018, 98, 4971-4977. [CrossRef] [PubMed]

42. Hidalgo, M.J.; Pozzi, M.T.; Furlong, O.J.; Marchevsky, E.J.; Pellerano, R.G. Classification of organic olives based on chemometric analysis of elemental data. Microchem. J. 2018, 142, 30-35. [CrossRef]

43. Llorent-Martínez, E.J.; Fernández-de Córdova, M.L.; Ortega-Barrales, P.; Ruiz-Medina, A. Quantitation of metals during the extraction of virgin olive oil from olives using ICP-MS after microwave-assisted acid digestion. J. Am. Oil Chem. Soc. 2014, 91, 1823-1830. [CrossRef] 